\title{
Aquatic Coleoptera (Hydraenidae and Elmidae) as indicators of the chemical characteristics of water in the Orbigo River basin (N-W Spain)
}

\author{
F. Garcia Criado ${ }^{1}$ \\ M. Fernandez Alaez ${ }^{2}$
}

Keywords : Hydraenidae, Elmidae, indicator species, León, Spain.

The responses of $32 \mathrm{Hydraenidae}$ and Elmidae species to six chemical parameters - alkalinity, $\mathrm{Cl}^{-}, \mathrm{SO}_{4}{ }^{--}, \mathrm{COD}^{-} \mathrm{NO}_{3}^{-}$, and total $\mathrm{P}$ have been analysed in the Orbigo river basin. The study of the distribution in relation to these factors by means of elaborating their ecological profiles pointed out the indicator species for each one of these parameters, according to their reciprocal species-factor information.

Hydraenidae et Elmidae (Coleoptera) indicateurs des caractéristiques chimiques de l'eau dans le bassin de la rivière Orbigo (N-O Espagne)

Mots clés : Hydraenidae, Elmidae, espèces indicatrices, León, Espagne.

Les réponses des 32 espèces d'Hydraenidae et d'Almidae à 6 paramètres chimiques - alcalinité, $\mathrm{Cl}^{-}, \mathrm{SO}_{4}{ }^{--}, \mathrm{DCO}^{\prime} \mathrm{NO}_{3}{ }^{-}$et $\mathrm{P}$ total - ont été analysées dans le bassin de la rivière Orbigo. L'étude de leur répartition en relation avec ces facteurs et la recherche de leurs profils écologiques ont mis en évidence les espèces indicatrices pour chacun de ces paramètres.

\section{Introduction}

Few studies have been reported on the families Hydraenidae and Elmidae in Spain. Furthermore, these studies have been limited to general considerations about habitat preferences. Only recently have authors such as Puig (1983), Sáinz-Cantero (1985), SáinzCantero \& Alba-Tercedor (1991), Díaz Pazos (1991) and Rico (1992) taken interest in determining the influence of physicochemical parameters on the distribution of species of these families.

1. Departamento de Biologia Animal. Facultad de Biologia. Universidad de León. 24071 León. Spain.

2. Departamento de Ecologia, Genetica y Microbiologia. Facultad de Biologia. Universidad de León. 24071 León. Spain.
In the province of León (N-W Spain) there has been no previous research of this kind. We have presented some preliminary data from our study carried out in the Órbigo basin (García Criado et al. 1994, García Criado et al., in press), and pointed out the tolerance limits of species for 10 physical and chemical parameters. In this work we extend these studies through more detailed investigation on the autoecology of species of both families. We aim at exposing the preferences of these species within the ranges of values found for several chemical factors.

\section{Material and methods}

The Órbigo basin lies mostly on siliceous soil, which alternates with calcareous soil in the northern areas (rivers Luna and Torrestío). The depth of the watercourses prospected was seldom more than $50 \mathrm{~cm}$.

Samples were taken seasonally over an annual cycle (from April 1991 to February 1992) and were collected 
from 37 sites along the rivers of the basin (Fig. 1), always from lotic environments (middle of the river) with pebble, cobble and boulder substratum. Beetles were collected by five minutes kick-sampling. Only presence/absence data of adults have been considered in this study.
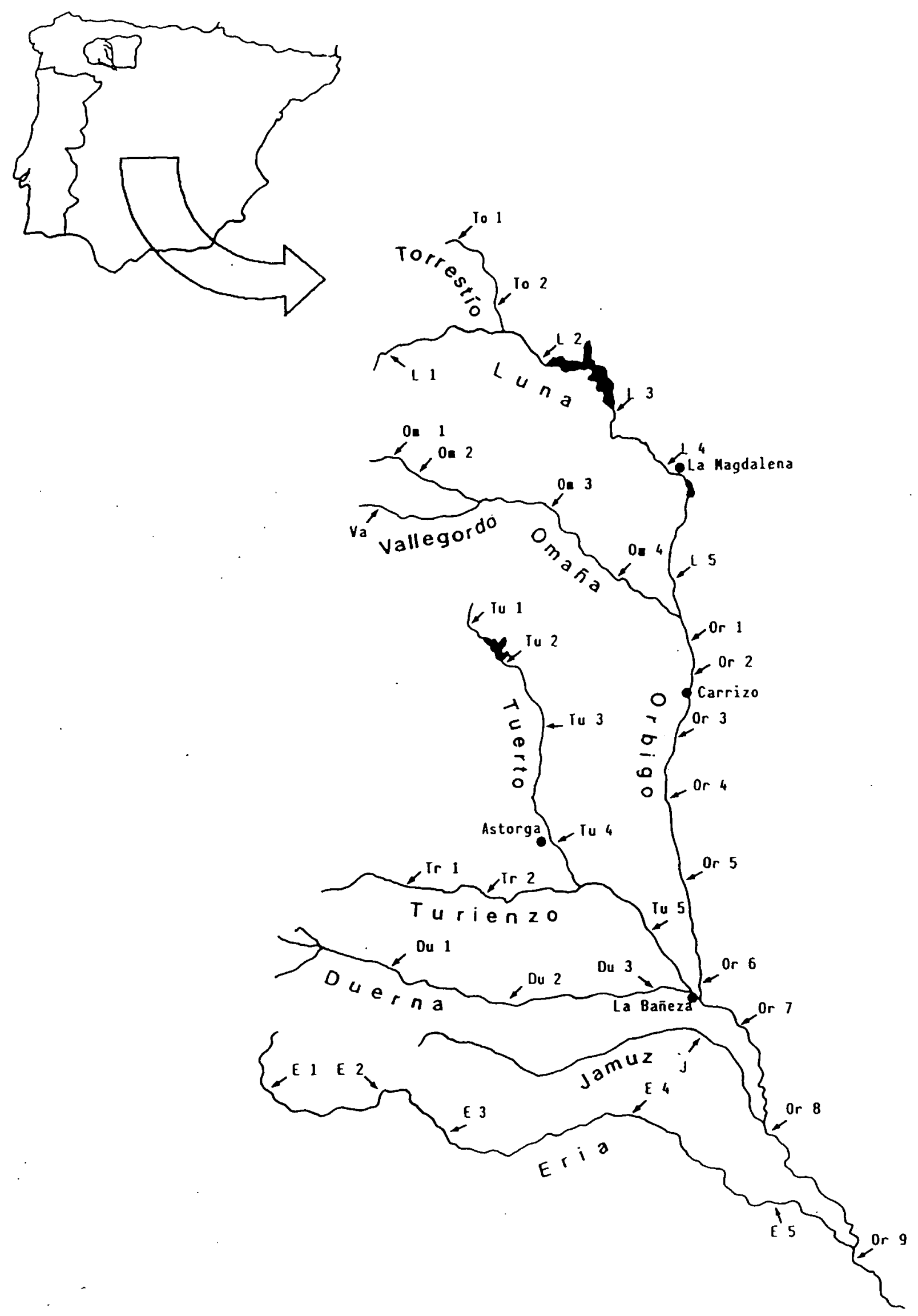

Fig. 1. Geographical situation of the Órbigo river basin and sampling sites.

Fig. 1. Situation géographique du bassin de la rivière Órbigo et stations de récoltes. 
All the 148 collected samples were taken into account together, regardless of their time of collection. Samples without Hydraenidae and Elmidae specimens were excluded from statistical processing, so that 101 was the final number of analyzed samples. These samples have been excluded as the lack of specimens is often due to causes other than chemical factors (high water levels and difficulty of sampling, siltation...). Besides their inclusion would have produced gaps in the profiles making it difficult to interpret the results.

Some factors likely to influence the distribution of Coleoptera or those positively correlated with the degree of organic pollution of water were considered in the analysis. Such selected factors are : alkalinity, $\mathrm{Cl}^{-}$, $\mathrm{SO}_{4}{ }^{--}$, chemical oxygen demand (COD), $\mathrm{NO}_{3}{ }^{-}$and total P. On the one hand, parameters such as $\mathrm{pH}$ and oxygen concentration were not included since their values throughout the basin were homogeneous and gave very little information on beetles distribution. Because conductivity is closely correlated with alkalinity, its inclusion was considered redundant.

The data were analyzed as follows. Firstly, the observed range of values for each habitat parameter (describer) was divided into a series of intervals (classes of describer). The samples were assigned to intervals according to their value for the describer. In this way, we established the number of samples occurring in each class of describer. Within each describer, care has been taken for the amplitude of intervals to be as homogeneous as possible. However, it was not possible to establish perfectly even intervals since it is convenient that the number of sites included in each class is as uniform as possible (Nakache 1973).

Firstly, it is important to determine the sampling quality. We calculated the entropy linked to the describer resulting from the sampling achieved by means of the following formula (Daget et al., 1972) :

$$
H(L)=\sum_{1}^{N k} \frac{R(k)}{N R} \log _{2} \frac{N R}{R(k)}
$$

where :

$\mathrm{R}(\mathrm{k})=$ number of sampling stations in every class of describer.

$\mathrm{NR}=$ total number of sampling stations (101).

$\mathrm{Nk}=$ number of classes of describer taken into account.

By comparing this value with the one for maximum entropy $\mathrm{H}(\mathrm{L})_{\max }=\log _{2}(\mathrm{Nk})$ we obtained the sampling quality $\mathrm{Q}(\mathrm{L})=\mathrm{H}(\mathrm{L}) / \mathrm{H}(\mathrm{L})_{\max }$, which indicates the loss of information in the sampling. Higher is the value, lower is the loss of information.
Next the profile of absolute frequencies was arranged, this is the number of samples in every class of describer in which each species is present. Although the pattern of this profile gives a preliminary idea of how the taxon responds to environmental variables, it may be misleading as the number of samples included in every class (that is to say, the overall profile) is not uniform. Besides, it is necessary to take into account the frequency of each species in the sample lot to correct the differences between the features of rare and frequent species. For these reasons, a profile of corrected frequencies $\mathrm{C}(\mathrm{k})$ was calculated in order to produce a more reliable image of the pattern of species distribution in relation to the describer. For this purpose we used the formula of Daget \& Godron (1982) :

$$
\mathrm{C}(\mathrm{k})=\frac{\mathrm{U}(\mathrm{k})}{\mathrm{R}(\mathrm{k})}: \frac{\mathrm{U}(\mathrm{E})}{\mathrm{NR}}
$$

where, besides the previous notation :

$C(k)=$ median frequencies of the species $E$ in every class of describer.

$\mathrm{U}(\mathrm{k})=$ number of sampling sites for every class of describer in which species $E$ is present.

$U(E)=$ total number of sampling stations in which species $E$ is present.

In order to select those taxa which give the most information with regard to every parameter, and avoid analysing all of them, the reciprocal species-describer information has been estimated. For this, we used the formula put forward by Godron (1968) :

$$
I(L, E)=\sum_{1}^{N k} \frac{U(k)}{N R} \log _{2} \frac{U(k)}{R(k)} \cdot \frac{N R}{U(E)}+\sum_{1}^{N k} \frac{V(k)}{N R} \log _{2} \frac{V(k)}{R(k)} \cdot \frac{N R}{V(E)}
$$

where, besides the previous notations :

$\mathrm{V}(\mathrm{k})=$ number of sampling stations for each interval in which species $E$ is absent.

$V(E)=$ total number of sampling stations in which species $\mathrm{E}$ is absent.

This value was taken as a measure of the indicator value of the species in relation to the describer. Since we are working with 32 species and 6 parameters it is not useful to analyze such a high number of features. It is much easier to handle just those features of species which provide useful information. These are the ones with highest $\mathrm{I}(\mathrm{L} ; \mathrm{E})$, that is, the highest indicator value for the describer. For every parameter we have selected the ten species whose values of reciprocal information species-describer were highest; their corrected frequencies are represented by histograms (Figs. 2-7). 
These are the species which are more highly linked to the factor under consideration.

Finally, we calculated the barycenter which allows us to summarize the information given by each one of the ecological profiles by means of a single value. It allows arrangement of the species along the ecological gradient and can be taken as a measure of its ecological optimum. For this calculation, the expression used was the following (Daget \& Godron 1982) :

$$
g=\frac{\sum_{n} m_{i} d_{i}}{\sum_{n} m_{i}}
$$

where :

$\mathrm{m}_{\mathrm{i}}=$ index of frequency (value of corrected frequency for every class of describer in which the species is present).

$\mathrm{d}_{\mathrm{i}}=$ number of the corresponding class.

\section{Results}

During the study 1,202 Hydraenidae and 2,771 Elmidae belonging to a total of 32 taxa were collected (Table I). Regarding the subspecies Limnius perrisi subcarinatus (Sharp 1872), we have followed Rico (1992), in synonymizing it with Limnius perrisi carinatus (Pérez-Arcas 1865).

Table I pres 'nts, for each species, the indicator value (reciprocal infor, lation species-describer) for each of the 6 variables studied, the barycenter, and the average indicator value (arithmetic mean of the indicator values for the six parameters). The latter value accounts for the potential of the species for being a global indicator for these parameters. This table shows as well the relative abundance, which is the percentage of samples in which the species was present.

The response of the species more closely linked (those giving more information) to each of the surveyed parameters is discussed below.

\subsection{Alkalinity (Fig. 2)}

The value of sampling quality observed for this variable was 0.87 , which is relatively high. This describer is, therefore, sufficiently sampled. From the species with high indicator value for this factor, Hydraena testacea, Hydraena inapicipalpis, and, to a lesser extent, Hydraena brachymera, are typical of scarcely alkaline waters ; the rest of the species were generally indifferent to this factor. Only Hydraena emarginata, though widely distributed, shows a slight tendency towards alkaline areas. This parameter, within the values existing in the basin, barely influences the distribution of the species, most of which exhibit wide tolerance.

\subsection{Choride (Fig. 3)}

A sampling quality of 0.88 was obtained. Because of the small number of samples with a $\mathrm{Cl}^{-}$concentration exceeding $10 \mathrm{mg} / \mathrm{l}$, all samples above this level were included in a single interval, even though values extended up to $23.2 \mathrm{mg} /$. Only two species, Elmis maugetii and Esolus pygmaeus, occur in the site with maximum chloride level. The most representative species for this parameter can be classified into :

- Taxa from areas with a low concentration : $H y$ draena inapicipalpis, Hydraena emarginata, Hydraena iberica and Elmis aenea. With a wider range, Hydraena brachymera may also be included in this group.

- Taxa from areas with a high concentration : Esolus pygmaeus is closely linked to sites with high levels of chloride, as shown by the values of corrected frequencies. Oulimnius rivularis shows a wider range.

- Taxa with a wide range of distribution : Elmis maugetii, Limnius opacus and Oulimnius troglodytes.

\subsection{Sulphate (Fig. 4)}

The sampling quality value is 0.84 . The maximum value of $\mathrm{SO}_{4}{ }^{-1}$ concentration was $34.7 \mathrm{mg} / \mathrm{l}$; again only Elmis maugetii and Esolus pygmaeus were present at sites with such concentration. Among the most significant species three groups can be considered:

- Taxa from areas with a low concentration : $H y$ draena brachymera, Hydraena inapicipalpis and $H y$ draena emarginata. Although with a wider distribution, Hydraena exasperata has a tendency to occur in areas with reduced level of sulphates.

- Taxa from areas with high concentrations : Esolus pygmaeus and, on a lesser scale, Oulimnius troglodytes.

- Widely distributed taxa : Elmis maugetii, Limnius opacus and Oulimnius rivularis. Though with important gaps in its profile, Esolus parallelepipedus also has a wide range.

\subsection{COD (Fig. 5)}

The sampling quality obtained was 0.95 . There was little polarization in the distribution of the studied taxa to this factor. Elmis aenea and Oulimnius tuberculatus were only present in areas with low COD, the rest of the species were in a relatively wide gradient of values or showed slightly defined tendencies. Among these species, Hydraena brachymera occurred more frequently in areas with low levels and Esolus parallelepipedus and Oulimnius troglodytes occurred in sites with relatively high values. However, no specimens were collected from localities with COD levels above $20 \mathrm{mg} \mathrm{O}_{2} / 1$, even though sites with values up to $53 \mathrm{mg} \mathrm{O}_{2} / 1$ were detected. 


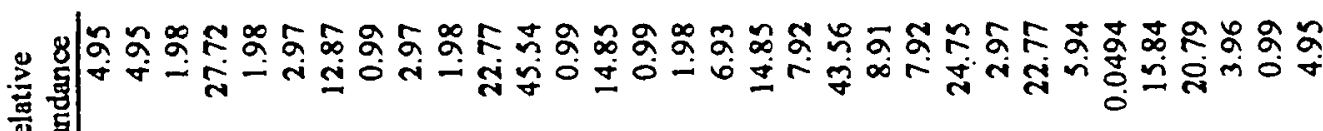
趗

흘

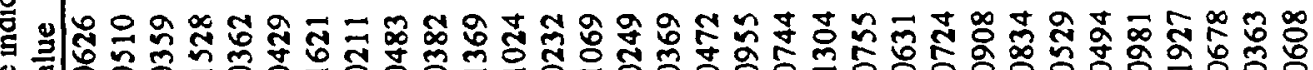

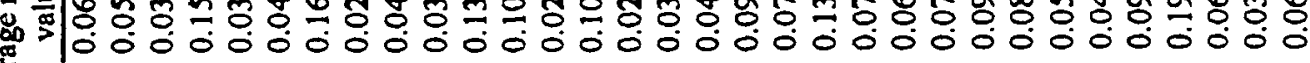
离

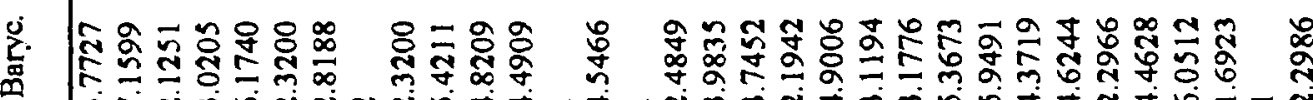

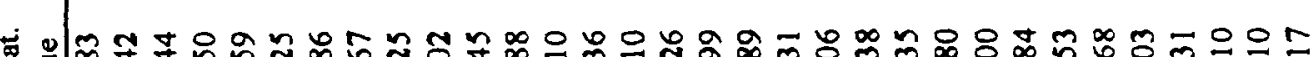

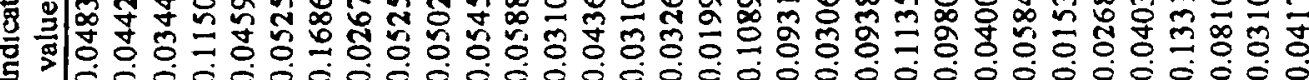

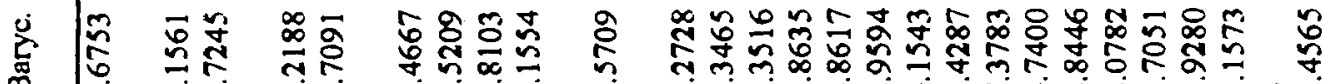

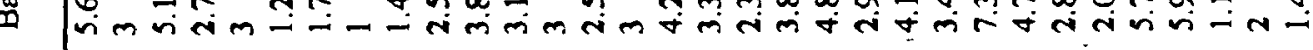

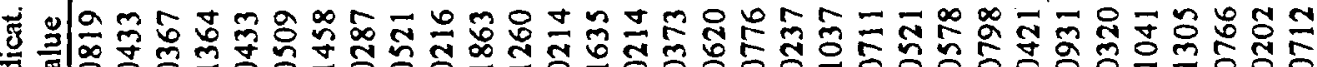
需

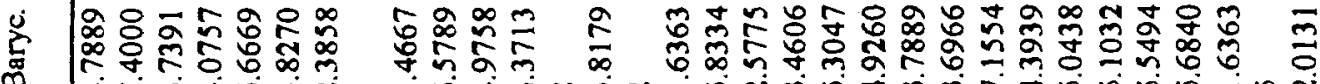

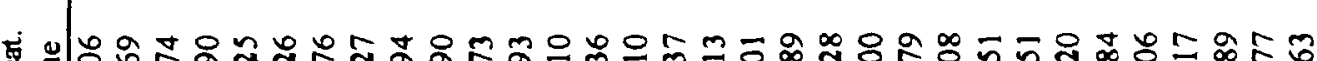

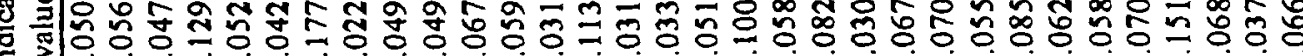

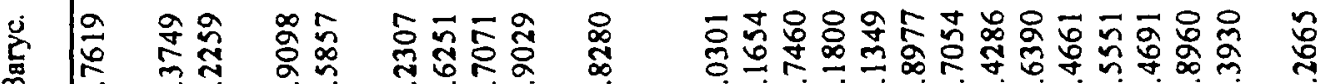

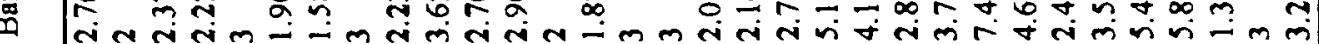

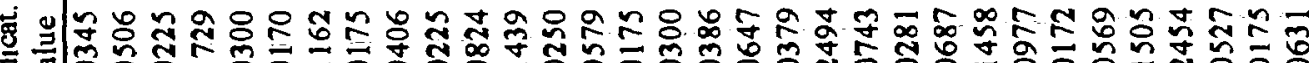

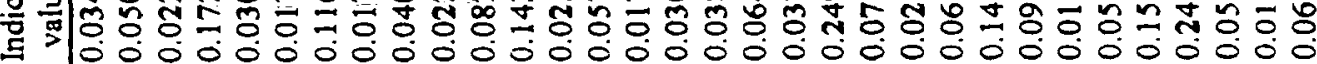

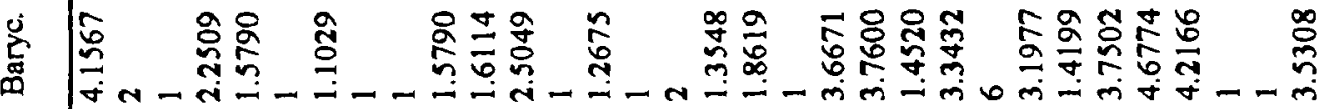

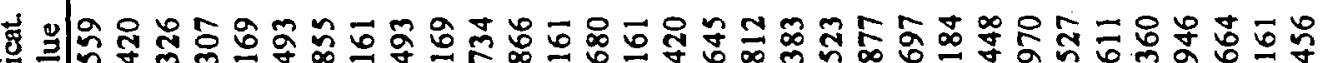
E

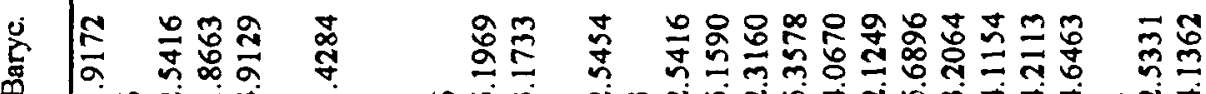
ตॉ

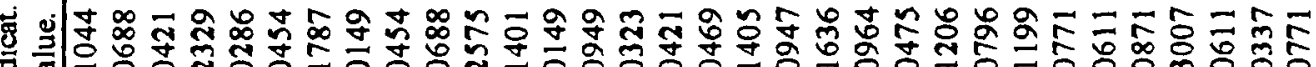

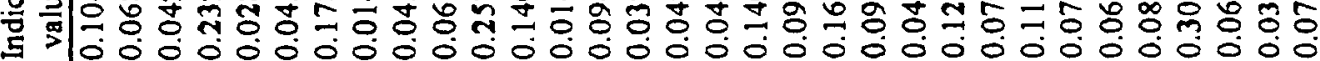

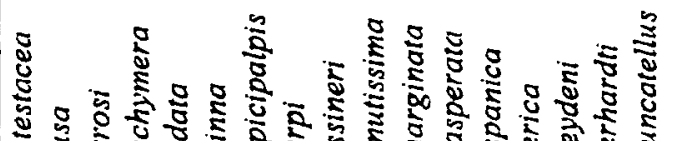

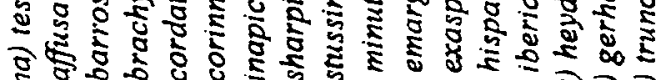

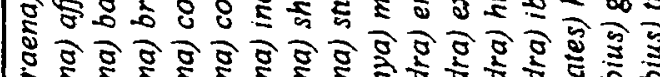

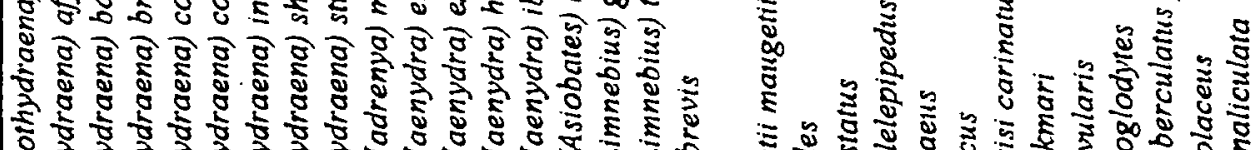

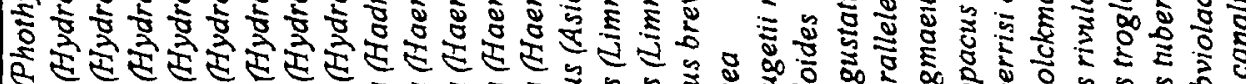

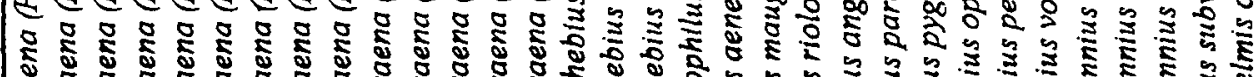

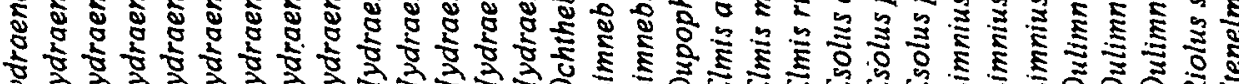

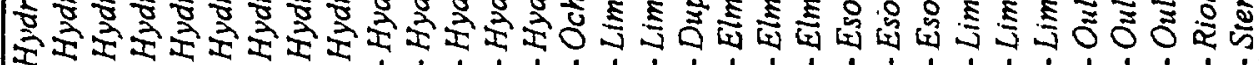

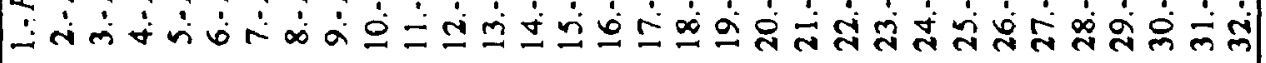


a) H. testacea

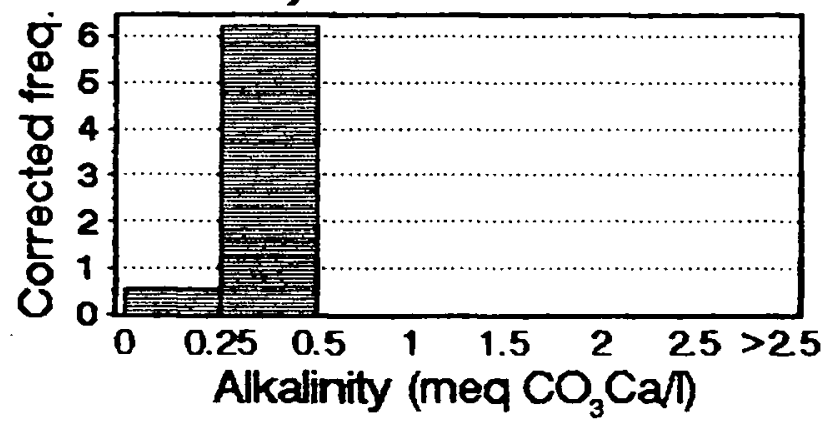

c) H. Inapicipaipls

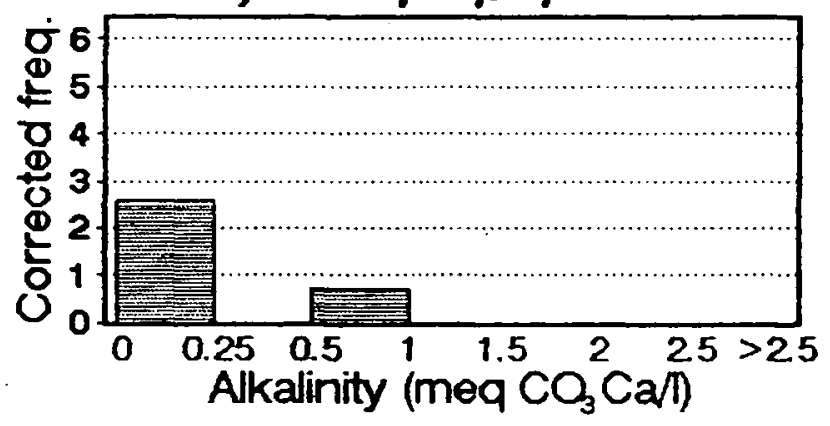

e) H. exasperata

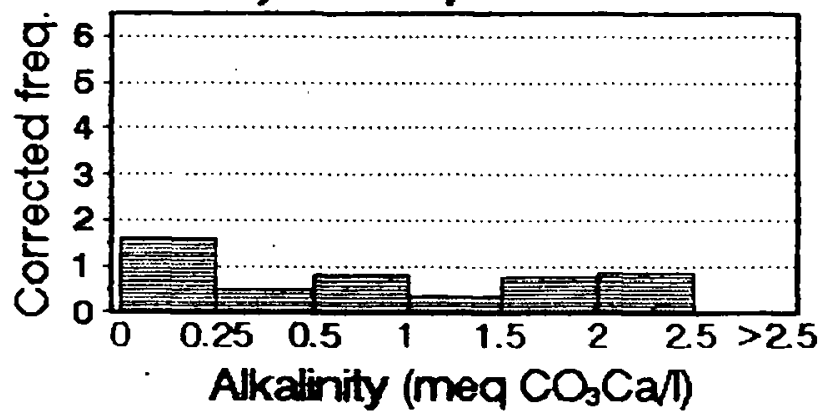

g) E maugetif

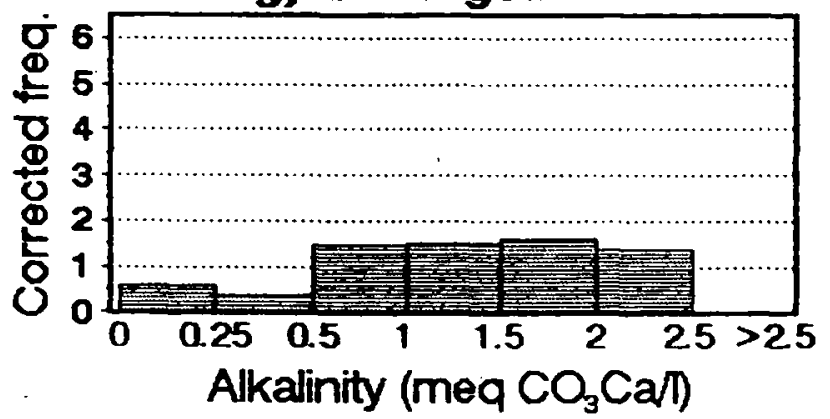

I) L opacus

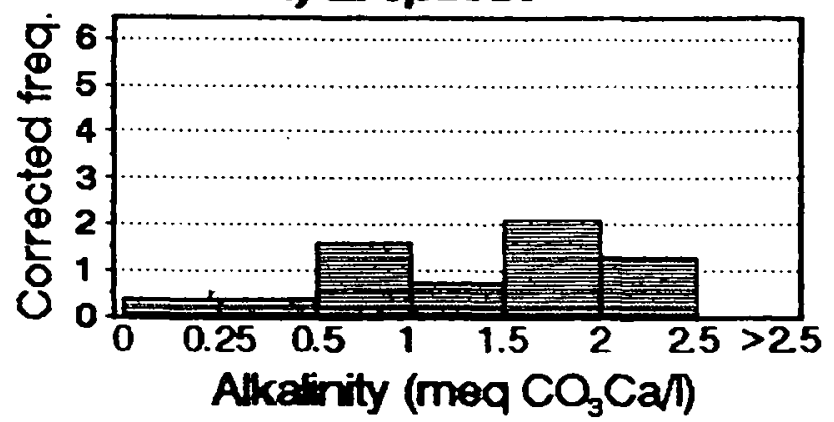

b) H. brachymers

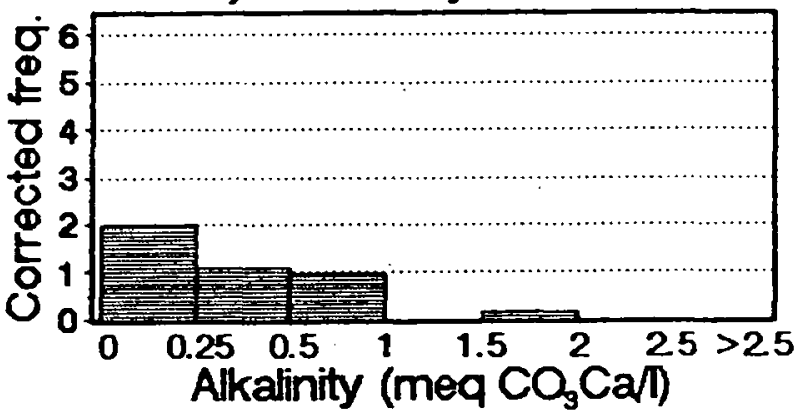

d) H. emarginata

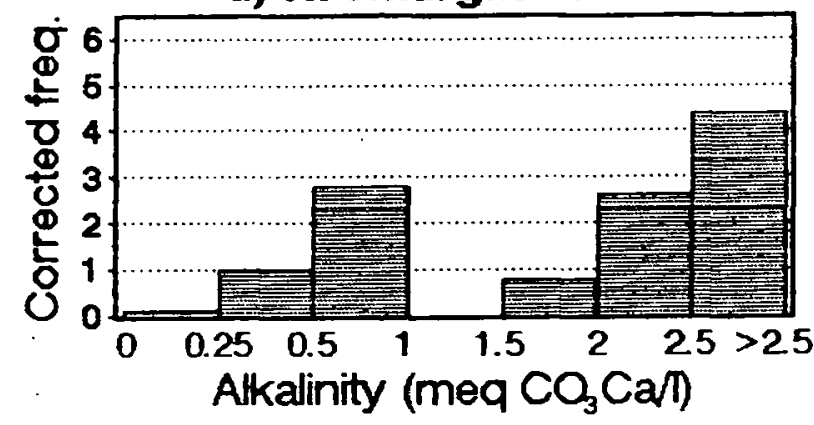

t) D. brevis

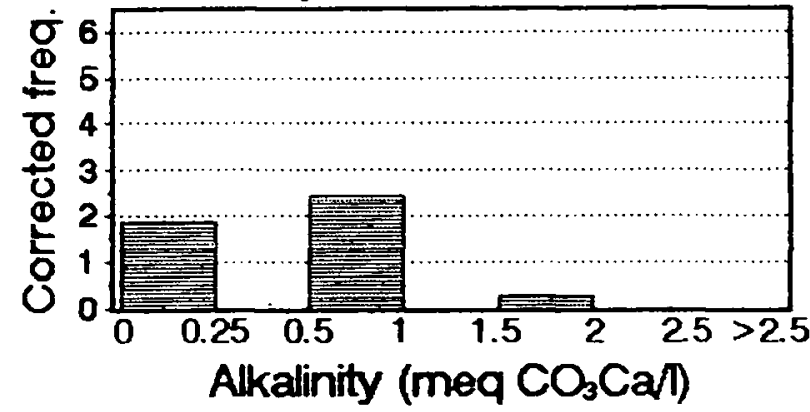

h) E. parallefeplpodus

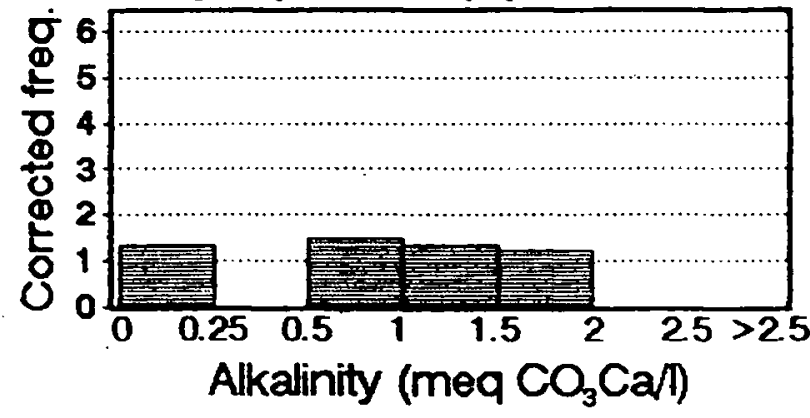

J) O. trogiodytes

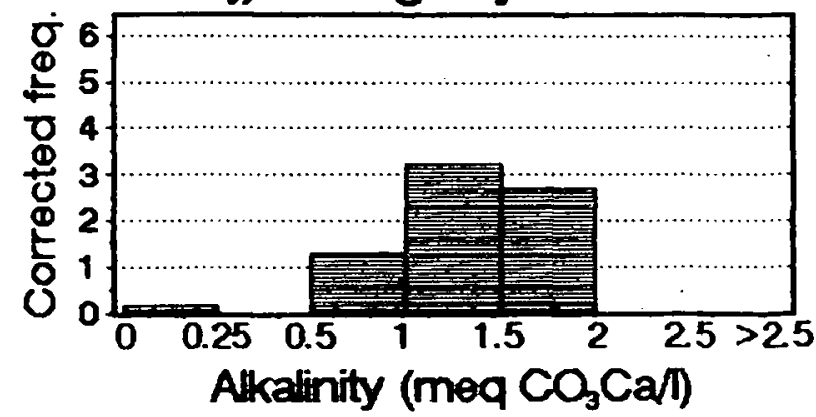

Fig. 2. Corrected frequencies of alkalinity for the ten taxa with highest indicator values for this parameter.

Fig. 2. Fréquences corrigées de l'alcalinité pour les 10 taxa avec les valeurs indicatrices les plus élevées pour ce paramètre. 

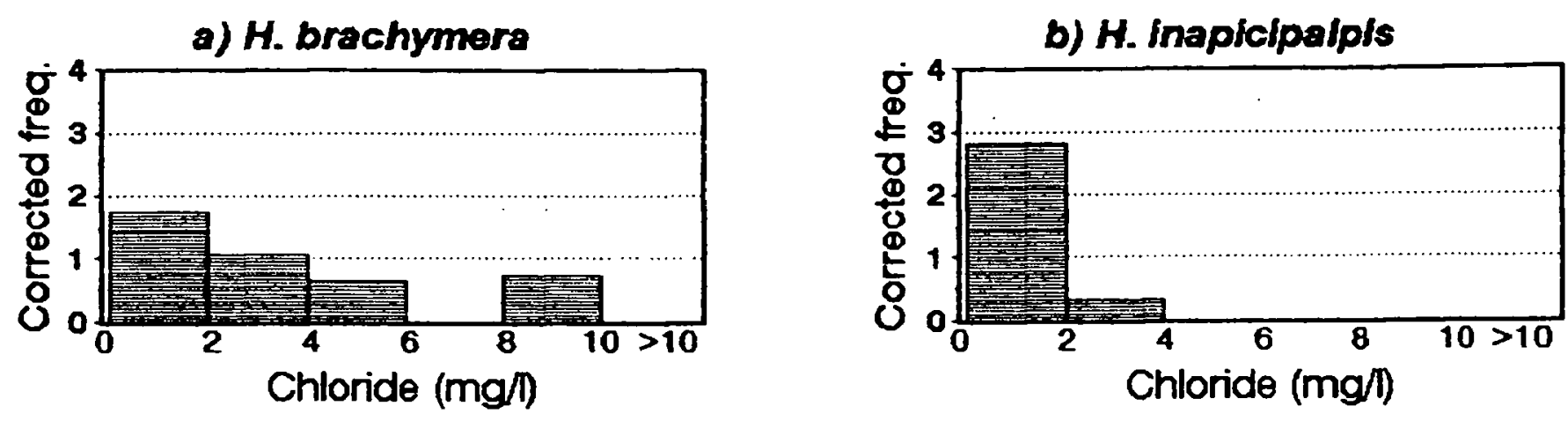

c) H. emarginata
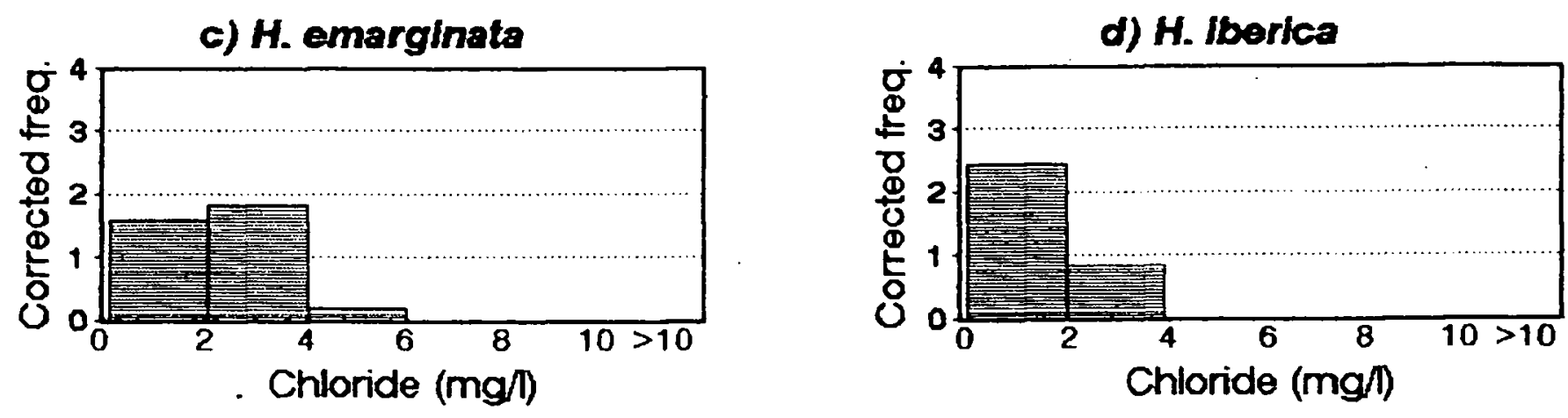

e) E. aenea
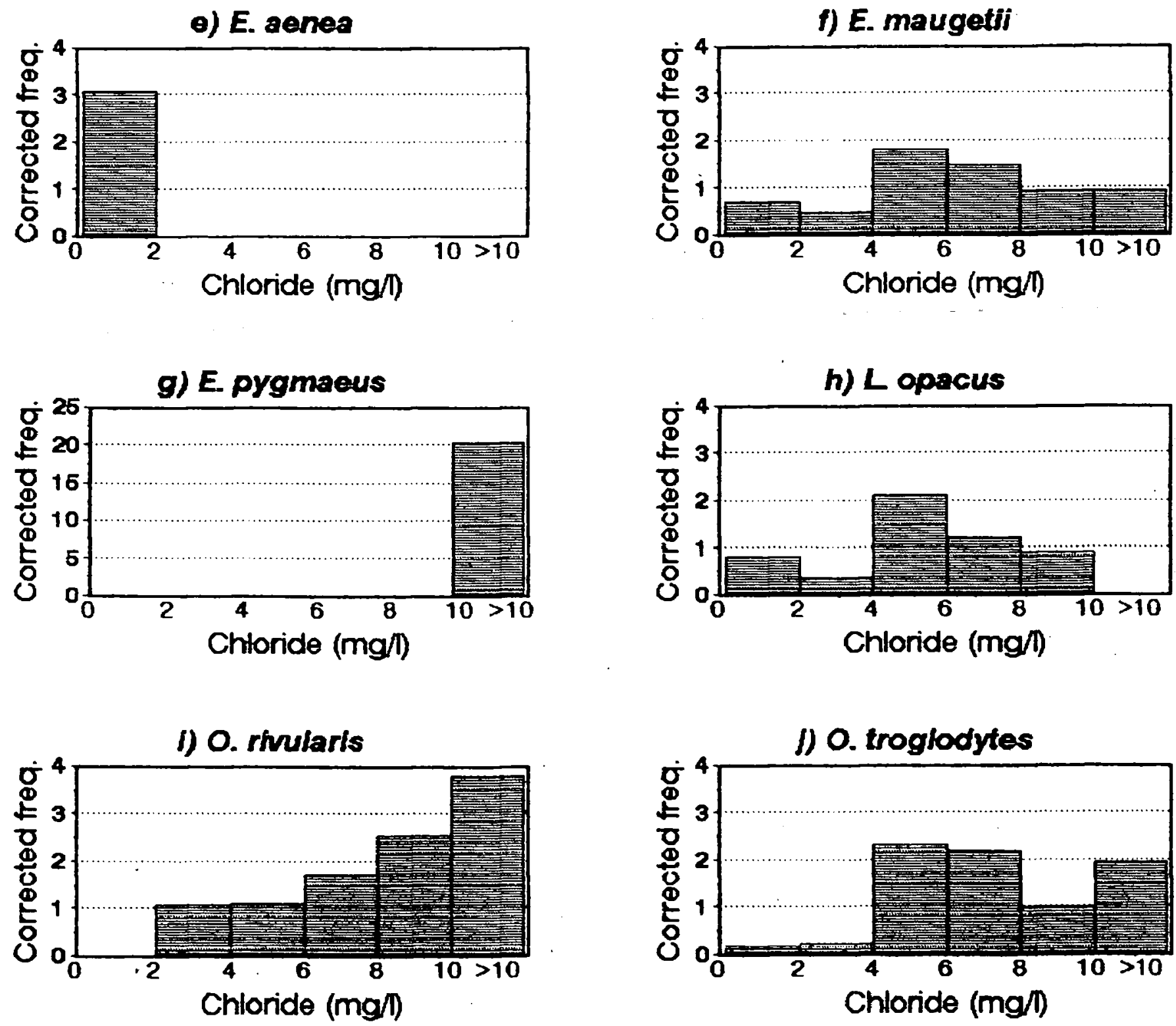

Fig. 3. Corrected frequencies of the chloride concentrations for the ten taxa with the highest indicator values for this parameter:

Fig. 3. Fréquences corrigées des concentrations de chlorure pour les 10 taxa avec les valeurs indicatrices les plus élevées pour ce paramètre. 
a) H. brachymera

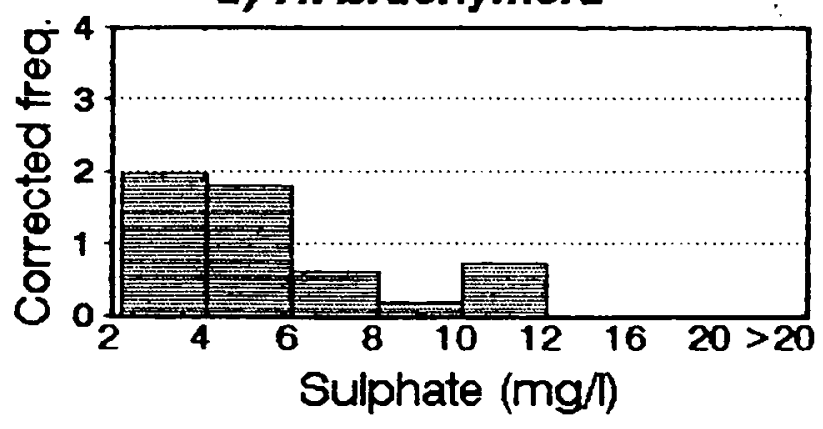

c) H. emarginata

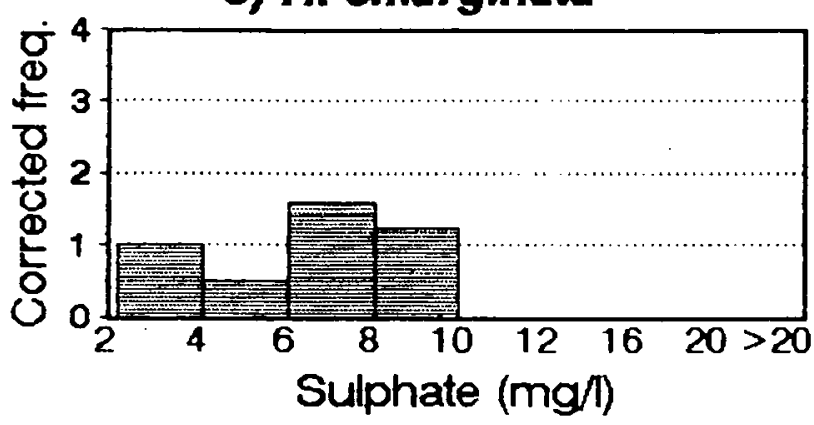

e) E. maugetii

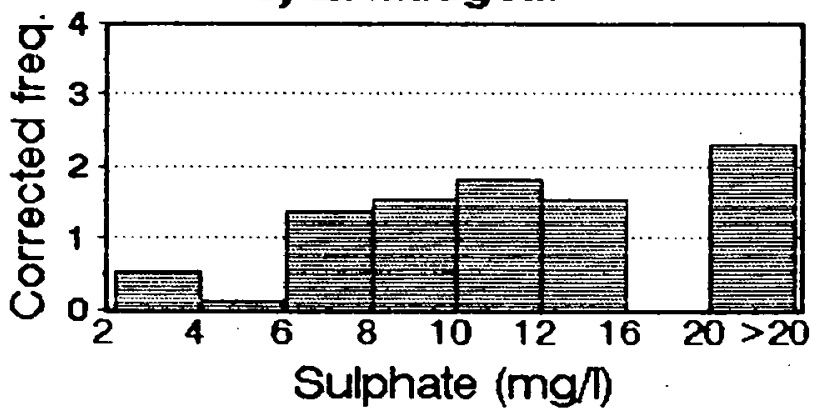

g) E. pygmaeus

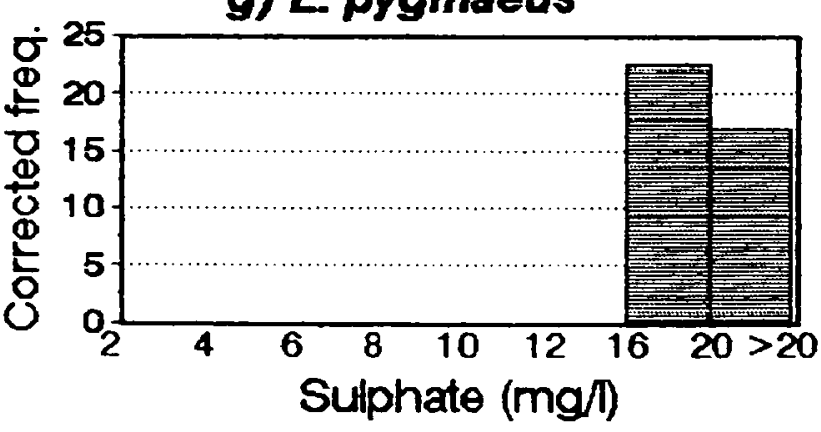

j) O. rivularis

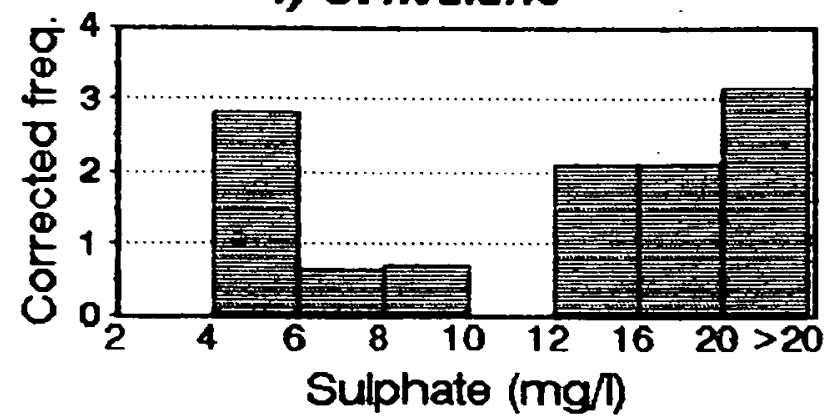

b) H. Inapicipajpis

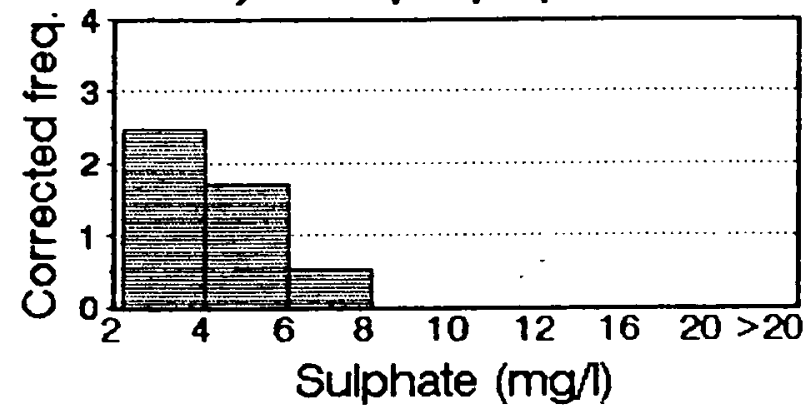

d) H. exasperata

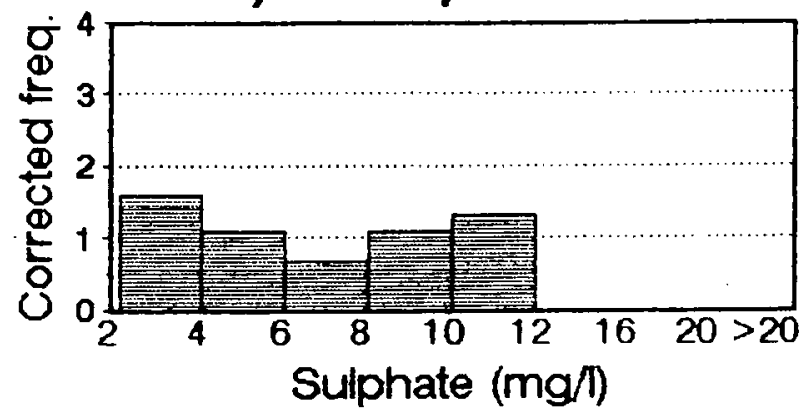

f) E. parallelepipedus

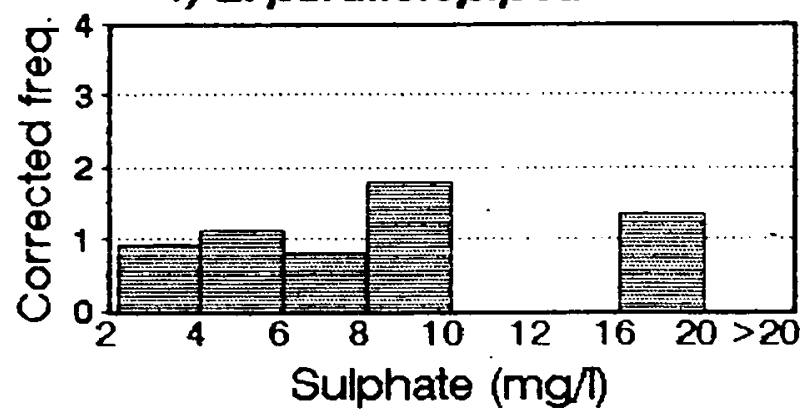

h) L opacus

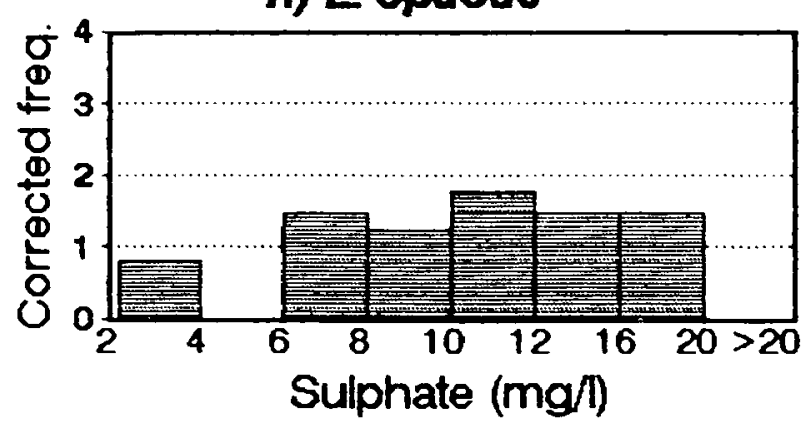

i) O. trogfodytes

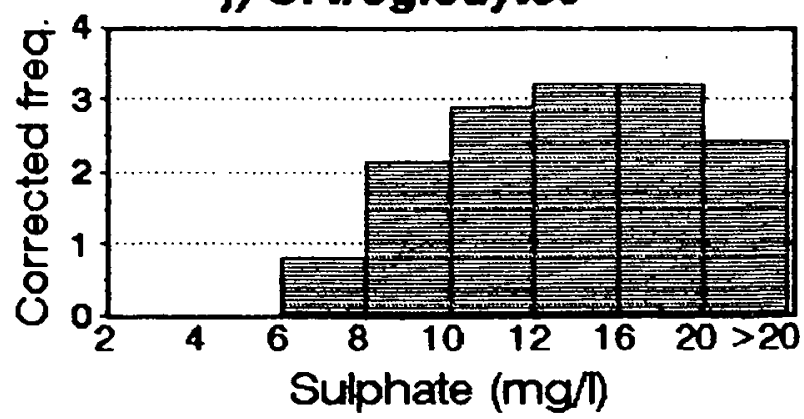

Fig. 4. Corrected frequencies of the sulphate concentrations for the ten taxa with the highest indicator values for this parameter.

Fig. 4. Fréquences corrigées des concentrations de sulfates pour les 10 taxa avec les valeurs indicatrices les plus élevées pour ce paramètre. 


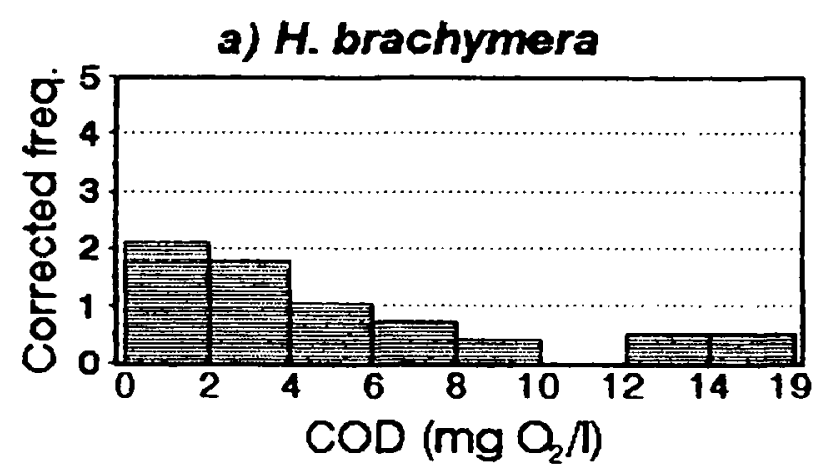

b) H. inapicipalp/s

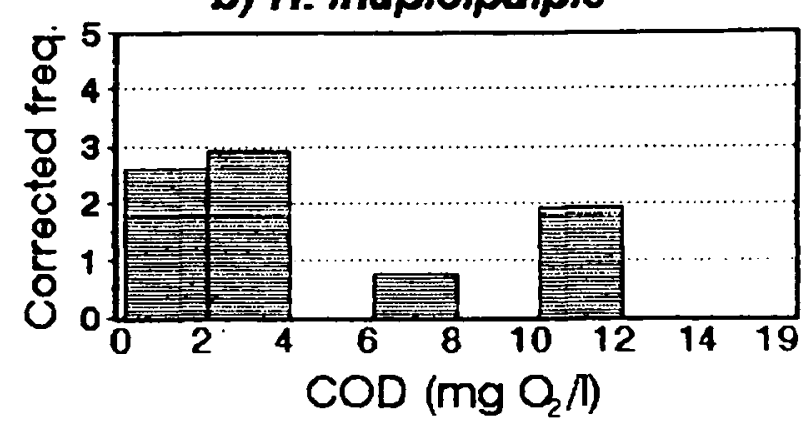

C) D. brevis

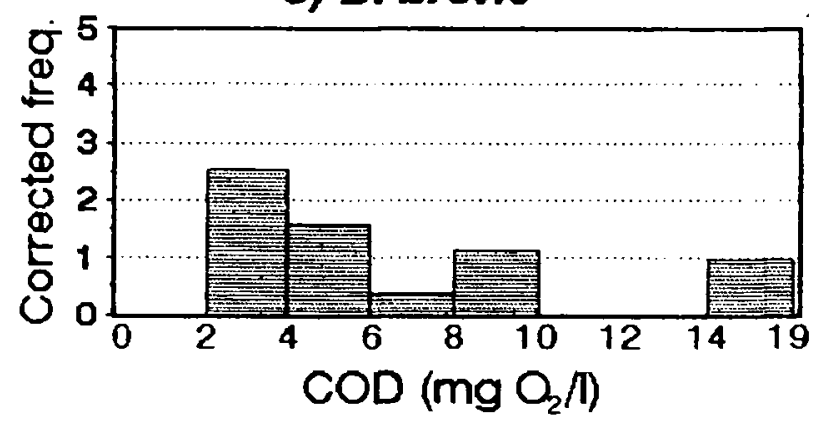

d) E. aenea.

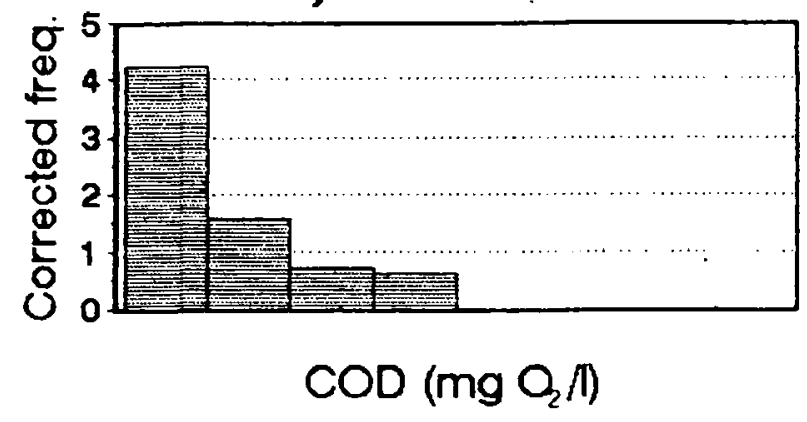

e) E. rioloides
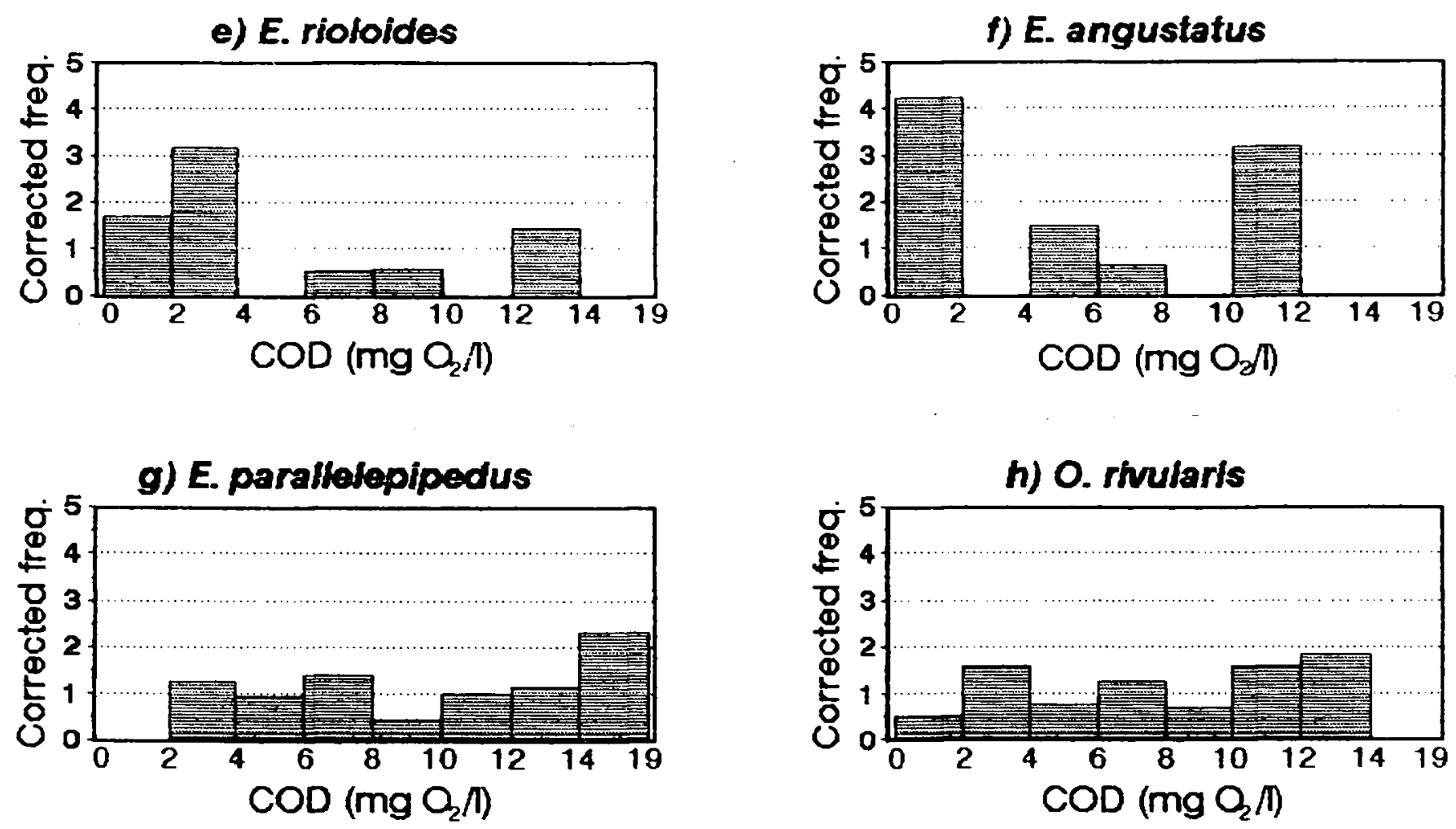

h) O. rivularis

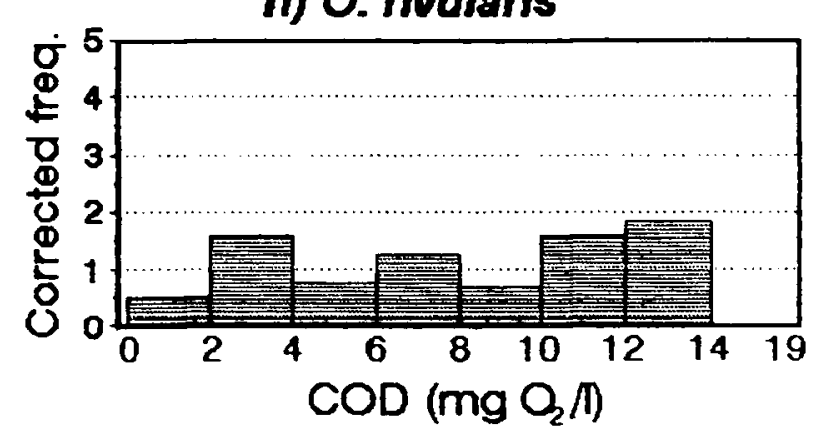

\section{i) O. troglodytes}
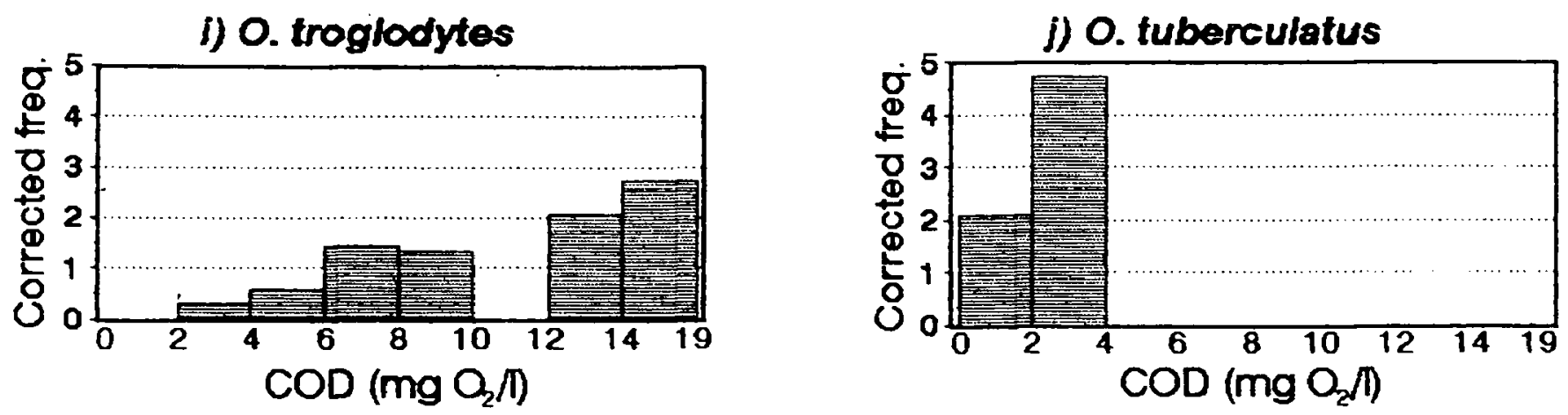

Fig. 5. Corrected frequencies of the chemical oxygen demand (COD) for the ten taxa with the highest indicator values for this parameter. Fig. 5. Fréquences corrigées de la demande chimique en oxygène (DCO) pour les 10 taxa avec les valeurs indicatrices les plus élevées pour ce paramètre. 


\subsection{Nitrate (Fig. 6)}

A sampling quality of 0.96 was obtained. The distribution of $\mathrm{NO}_{3}{ }^{-}$concentrations found in the basin was skewed towards low values $(<1 \mathrm{mg} / \mathrm{l})$, therefore uneven intervals, of $0.2,0.5,1$ and a final interval including just over 2 units were used. Nitrate levels in the basin were found not above $6.89 \mathrm{mg} / \mathrm{l}$. Due to this scarce variation no noticeable differences can be observed in the response of the species, which on the whole occupied a wide range of values. Only Hydraena inapicipalpis, Oulimnius tuberculatus and, to a lesser extent, Dupophilus brevis were restricted to areas with the lowest concentration.

\subsection{Total phosphorus (Fig. 7)}

The sampling quality for this parameter was 0.92 . Phosphorus levels were relatively low, not exceeding $4 \mu \mathrm{M}$ of $\mathrm{PO}_{4}{ }^{3-}$. Hydraena inapicipalpis and Limnius perrisi carinatus showed preference for low values. A similar tendency, though less strong, was exhibited by Hydraena iberica. The rest of the species are present along the greater part, or all, of the gradient although Oulimnius rivularis and Oulimnius troglodytes had a propensity for points with the highest concentrations and Hydraena brachymera showed an inclination for those points with the lowest concentrations.

\section{Discussion}

These results are a preliminary approach to the autoecology of some species found in the basin. In order to reach final conclusions concerning the preferences of each species, further studies extending the sampling area to differently-characterized basins are required.

When it comes to interpreting the results obtained, firstly we have to keep in mind that altitudinal and organic pollution gradients largely overlap in this basin (Fernández Aláez et al., 1988). For this reason it is difficult to distinguish whether the distribution of a certain taxon depends on the chemical characteristics of water, or on factors linked to altitude or to the distance from the river source. On the other hand, we must not forget that this research solely deals with lotic environments. Therefore, specimens peculiar to lenitic surroundings, such as Hydraena testacea, have only been exceptionally collected. It is very likely that lenitic species will display noticeably different ecological preferences.

Levels of nitrate, total phosphorus, chloride, sulphate and COD were not found to be very high. Conquently, we cannot strictly talk of species tole- rant to pollution. Actually, extensive literature supports the fact that these families are generally quite sensitive to the degradation of streams (Thomas 1988, Rico 1992). However, the stated data here below are valuable in relative terms, as they allow us to compare various areas from the same basin. At the same time, they underline the existence of some taxa which are more demanding, in connection with those parameters, than others.

Of all 32 taxa collected, 18 proved to be indicators for at least one of the describers used. That number is reduced to 11 if we leave aside those taxa which are only indicators of 1 or 2 describers. Those 11 species are Hydraena brachymera, Hydraena inapicipalpis, Hydraena emarginata, Hydraena exasperata, Hydraena iberica, Dupophilus brevis, Elmis maugetii, Esolus parallelepipedus, Limnius opacus, Oulimnius rivularis and Oulimnius troglodytes. These taxa are likewise the ones with the greatest average indicator value. Thus, these taxa give more global information about the variables under consideration. They are also the most abundant species in the basin (Table I).

With regard to pollution, shown by the levels of nitrate, phosphorus, COD, chloride and sulphate, the species Hydraena brachymera, Hydraena inapicipalpis, Elmis maugetii, Oulimnius rivularis, and $\mathrm{Ou}$ limnius troglodytes are indicators for at least 4 of these 5 factors. Hydraena inapicipalpis especially shows a remarkable preference for low levels of pollution, a feature already pointed out by Díaz Pazos (1991). Hydraena brachymera has a wider range, although with a tendency to appear in the less polluted areas ; the only exception is with regard to $\mathrm{NO}_{3}{ }^{-}$, for which it occupies a wide gradient. However Díaz Pazos (op. cit.) indicates that in his study area it was not affected by organic pollution. Elmis maugetii, Oulimnius rivularis and Oulimnius troglodytes occur over a wide range of chemical conditions and were found in even the most degraded points along the basin. This same thing has been demonstrated by Rico (1992) with Oulimnius troglodytes, which is found, as he states, in areas with the highest eutrophication. Elmis maugetii, although also present in the most polluted reaches, occurs over a wide range of pollution and shows preference for the intermediate part of it. Such a relative tolerance to pollution has been observed by Puig (1983) at the Llobregat river, by Rico (op. cit.) in Biscay, and by Grasser (1994) in Austria.

As for the rest of the taxa we can point out that $\mathrm{Hy}$ draena iberica is present in the cleanest waters, which agrees once again with what is stated by Díaz Pazos (1991) ; this fact is revealed by its response to the le- 


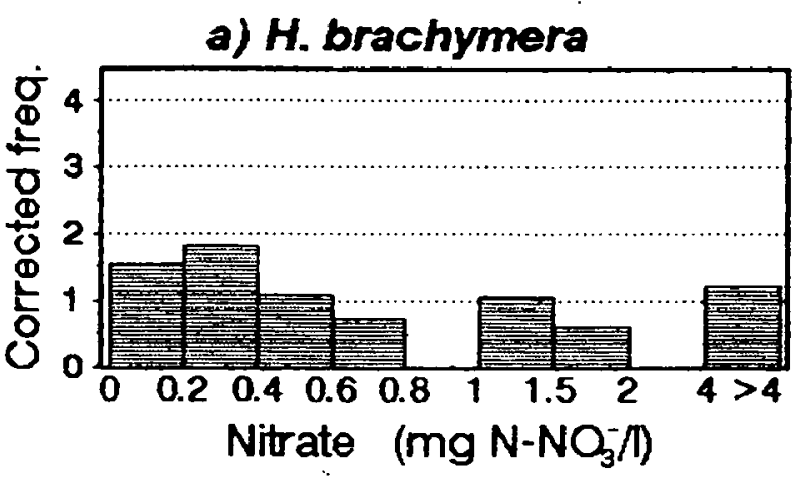

c) H. iberica

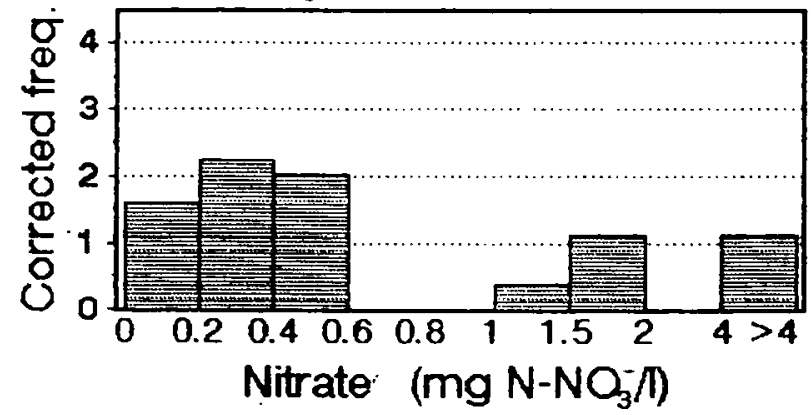

e) E. mauget $j i$

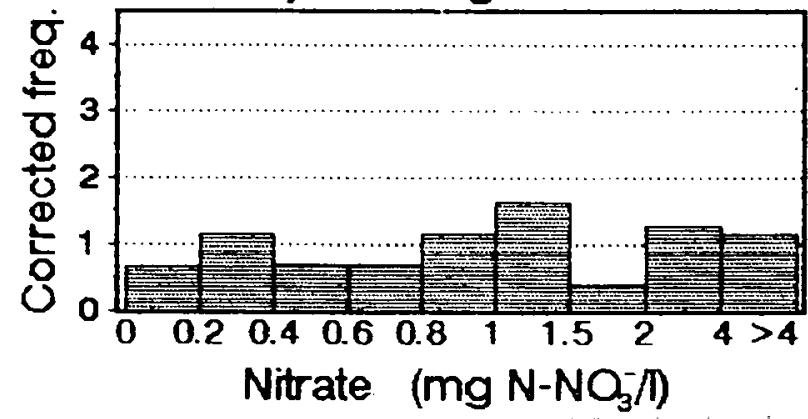

g) L opacus

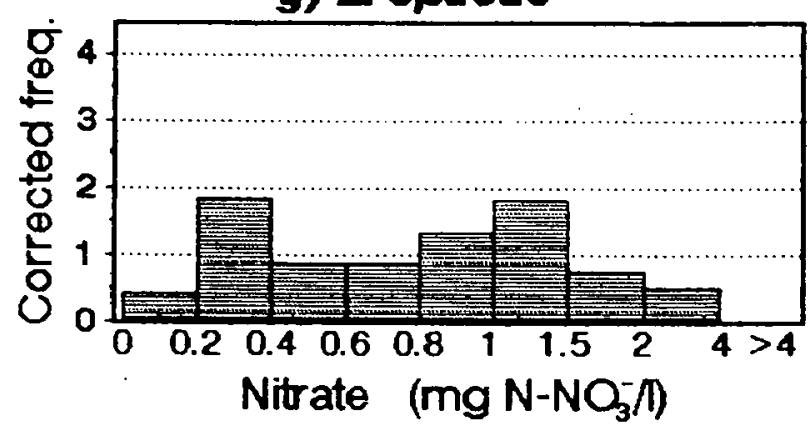

i) O. trogfodytes

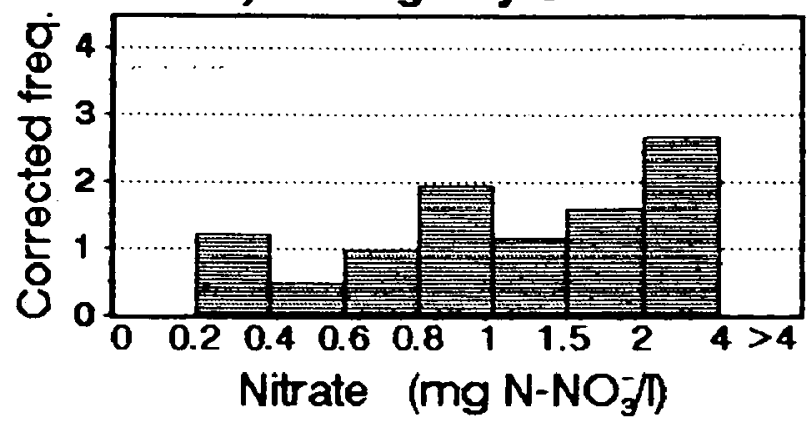

b) H. inaplcipalpis

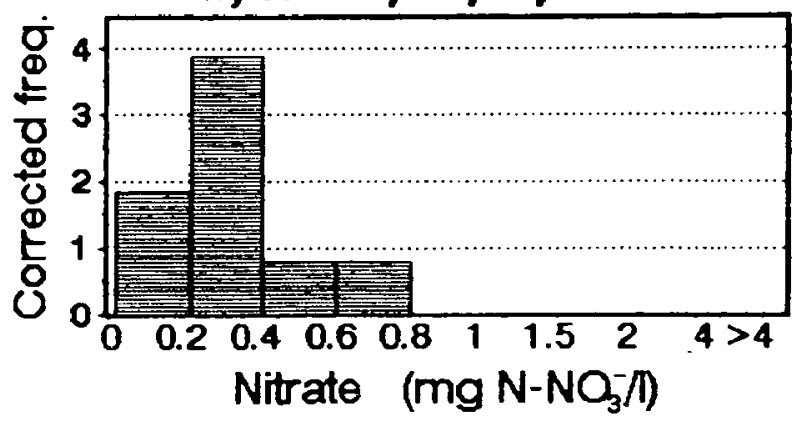

d) D. brevis

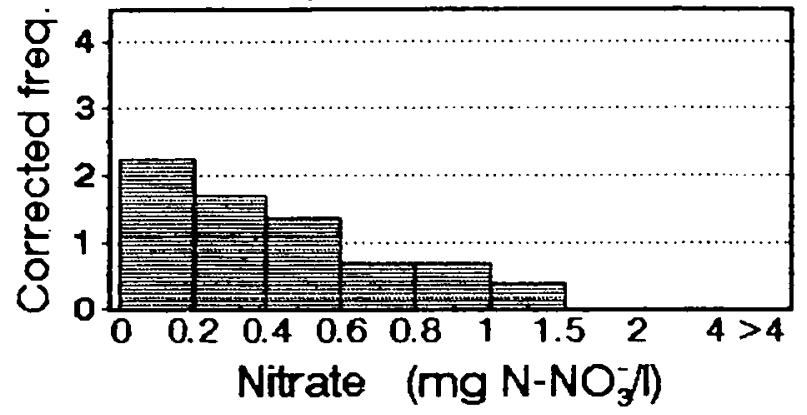

f) E. parallelepipedus

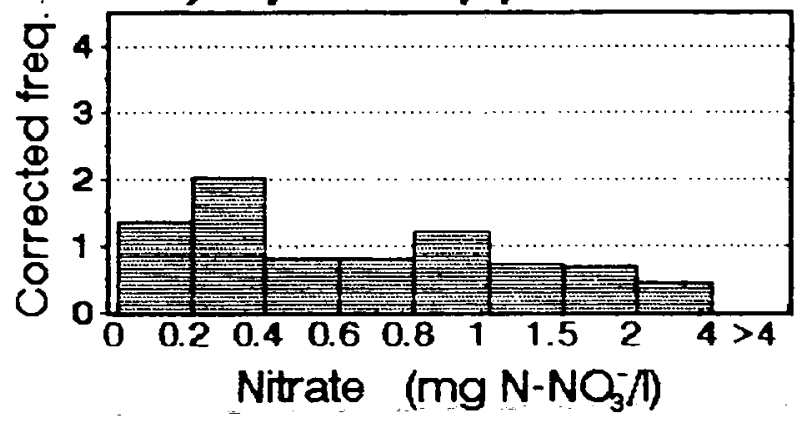

h) O. rivularis

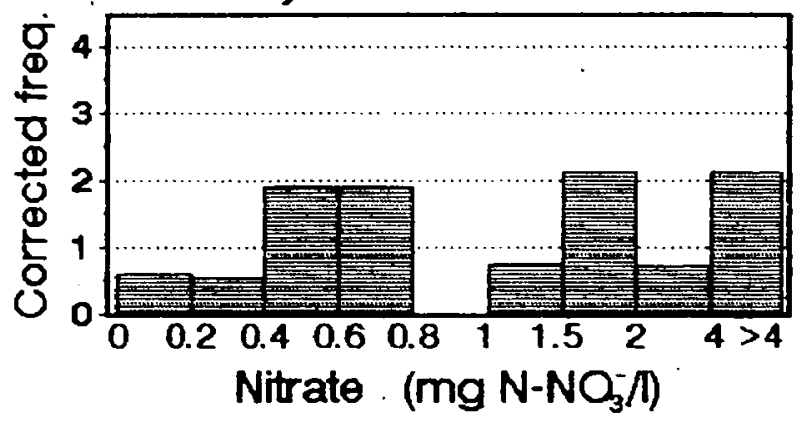

J) O. tuberculatus

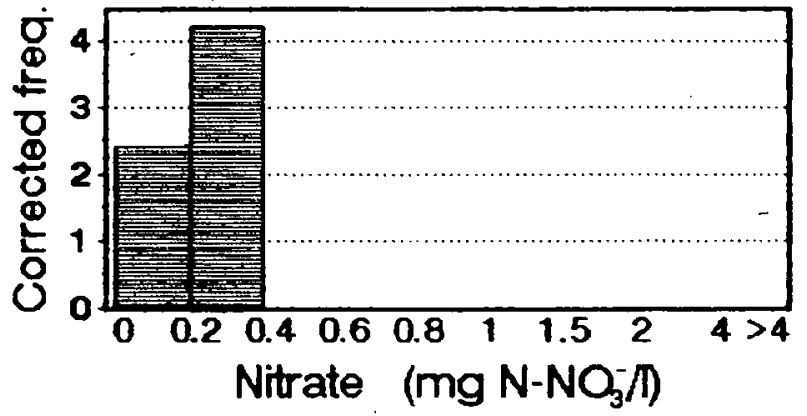

Fig. 6. Corrected frequencies of $\mathrm{NO}_{3}{ }^{-}$concentrations for the ten taxa with the highest indicator values for this parameter.

Fig. 6. Fréquences corrigées des concentrations de nitrates pour les 10 taxa avec les valeurs indicatrices les plus élevées pour ce paramètre. 
a) H. testacea

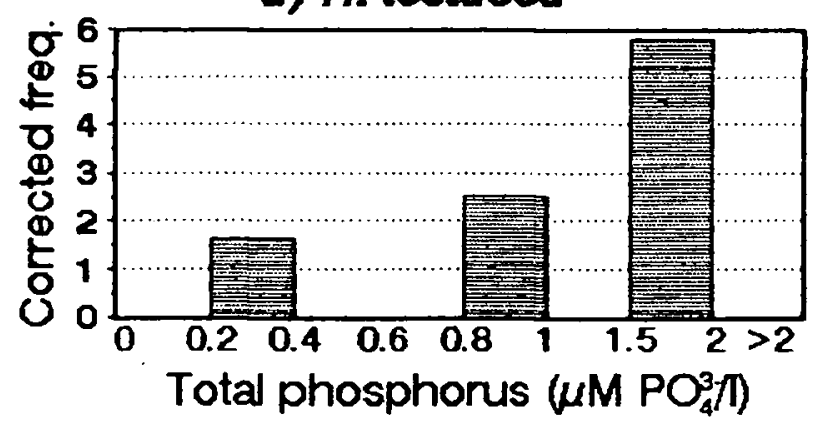

c) H. inaplcipalpis

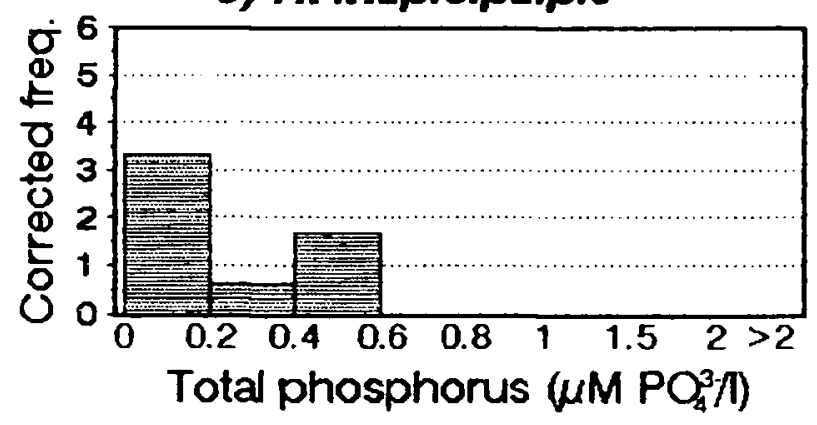

e) H. exasperata

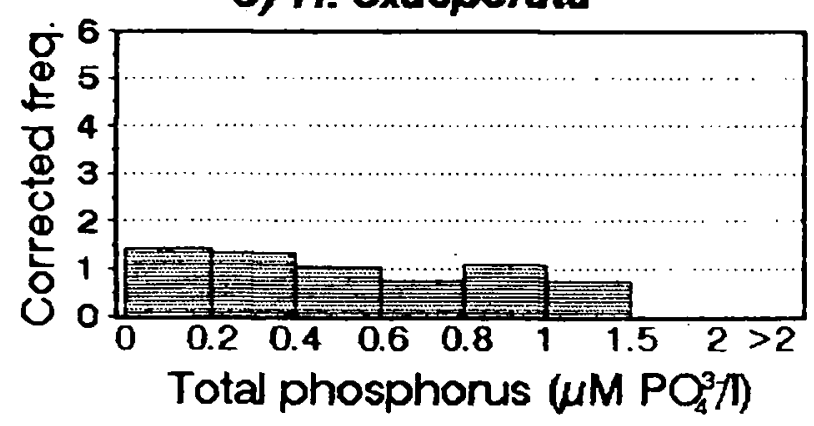

g) E. maugotij

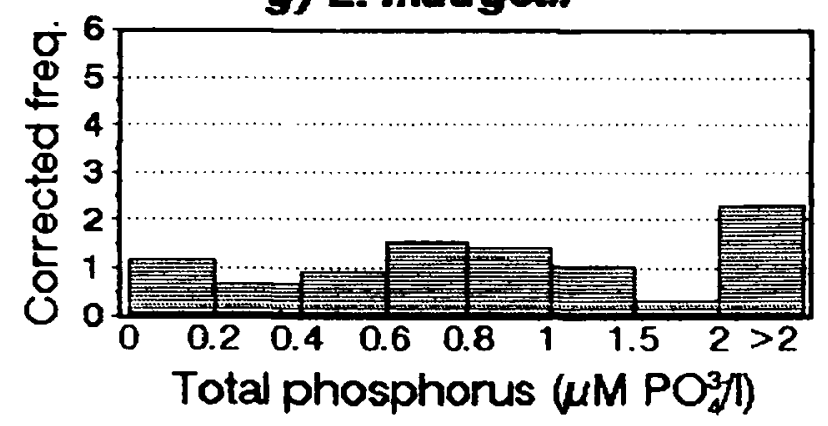

J) O. rivularis

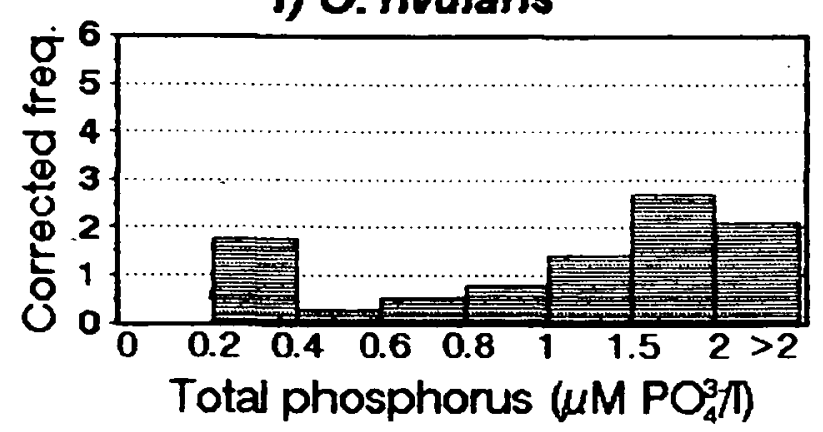

b) H. brachymera

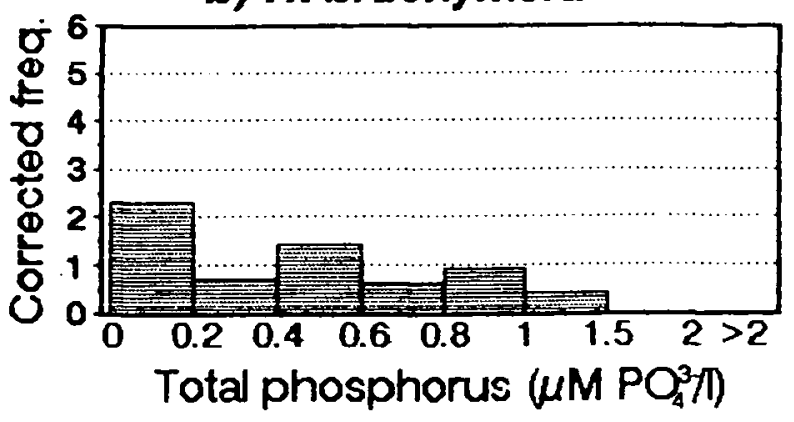

d) H. emarginata

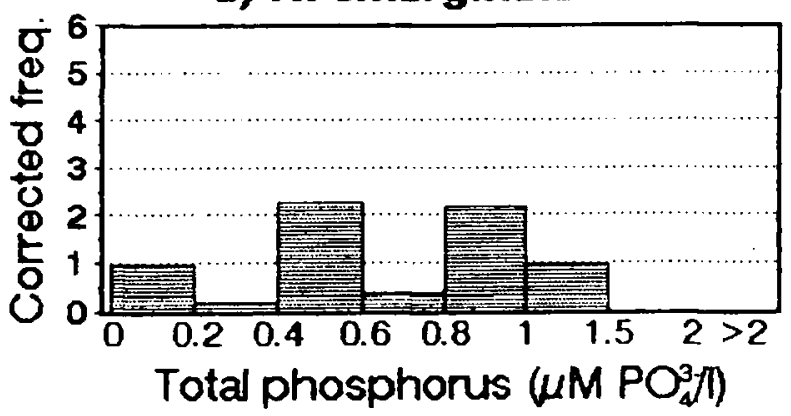

f) H.iberica

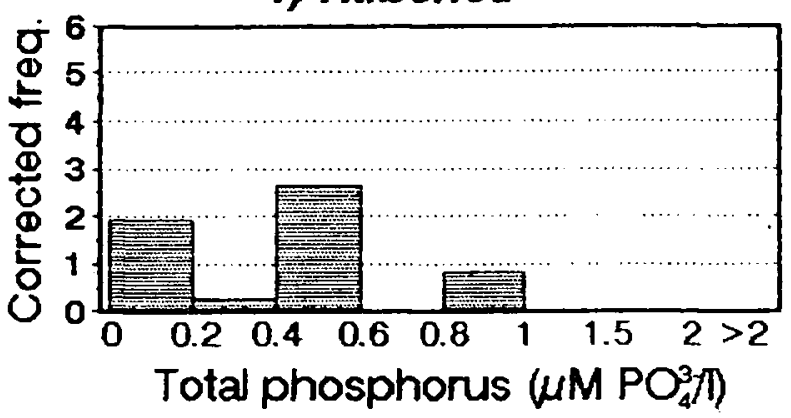

h) L perrisi carinatus

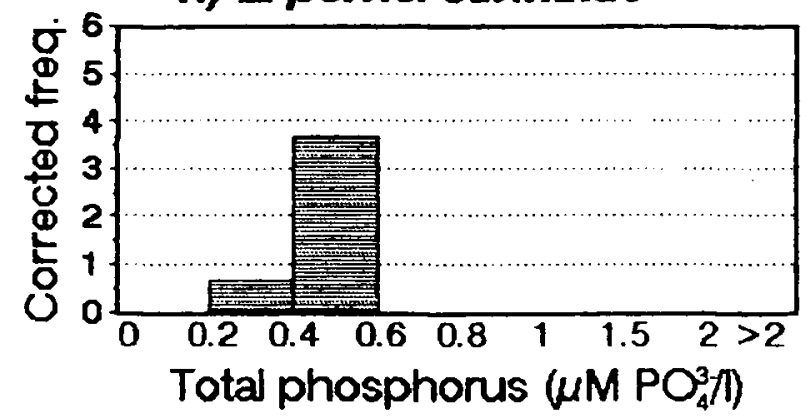

i) O. trogfodytes

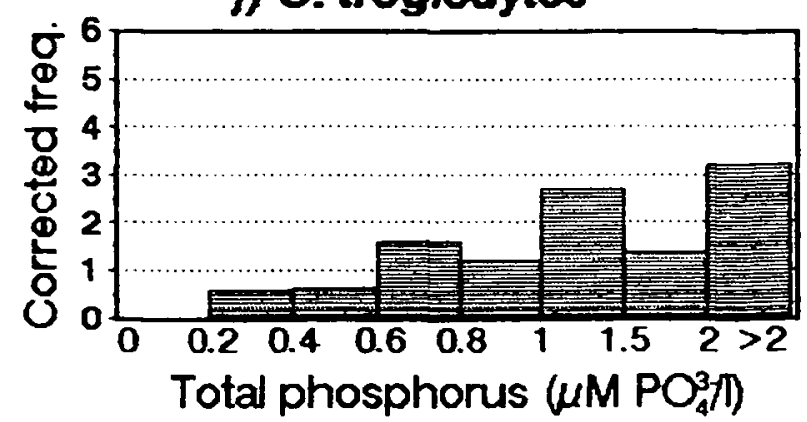

Fig. 7. Corrected frequencies of total $P$ concentrations for the ten taxa with the highest indicator values for this parameter.

Fig. 7. Fréquences corrigées des concentrations de phosphore total pour les 10 taxa avec les valeurs indicatrices les plus élevées pour ce paramètre. 
vels of phosphorus and chloride. The same applies to Hydraena emarginata. On the other hand, Hydraena exasperata, the hydraenid species with the widest distribution in the Órbigo basin, tolerates a wide range of the surveyed parameters. Within the Elmidae family, Limnius opacus and Esolus parallelepipedus also show a relatively broad gradient of these factors, with no definite tendency towards either end.

The case of Esolus pygmaeus is striking. This species, scarcely represented in the basin, only occurred in three sites of its final reaches, precisely where pollution levels are highest. This can be observed in the corrected frequencies for chloride and sulphate (Figs 6 ,
7). This fact could lead us to think that this taxon is relatively tolerant of organic pollution. Notwithstanding, the number of specimens collected was low and there is little available data to make final statements.

The analysis of the barycenter values (Figs 8,9 ) allows us to notice clearly and briefly what we have discussed so far. Esolus pygmaeus stands out, since it is distinguished by its tolerance to relatively high levels of nitrate, total phosphorus, COD, chloride and sulphate. Next to it stands Oulimnius troglodytes. Elmis maugetii, Limnius opacus and Oulimnius rivularis exhibit more intermediate positions, although they also show a certain degree of tolerance.

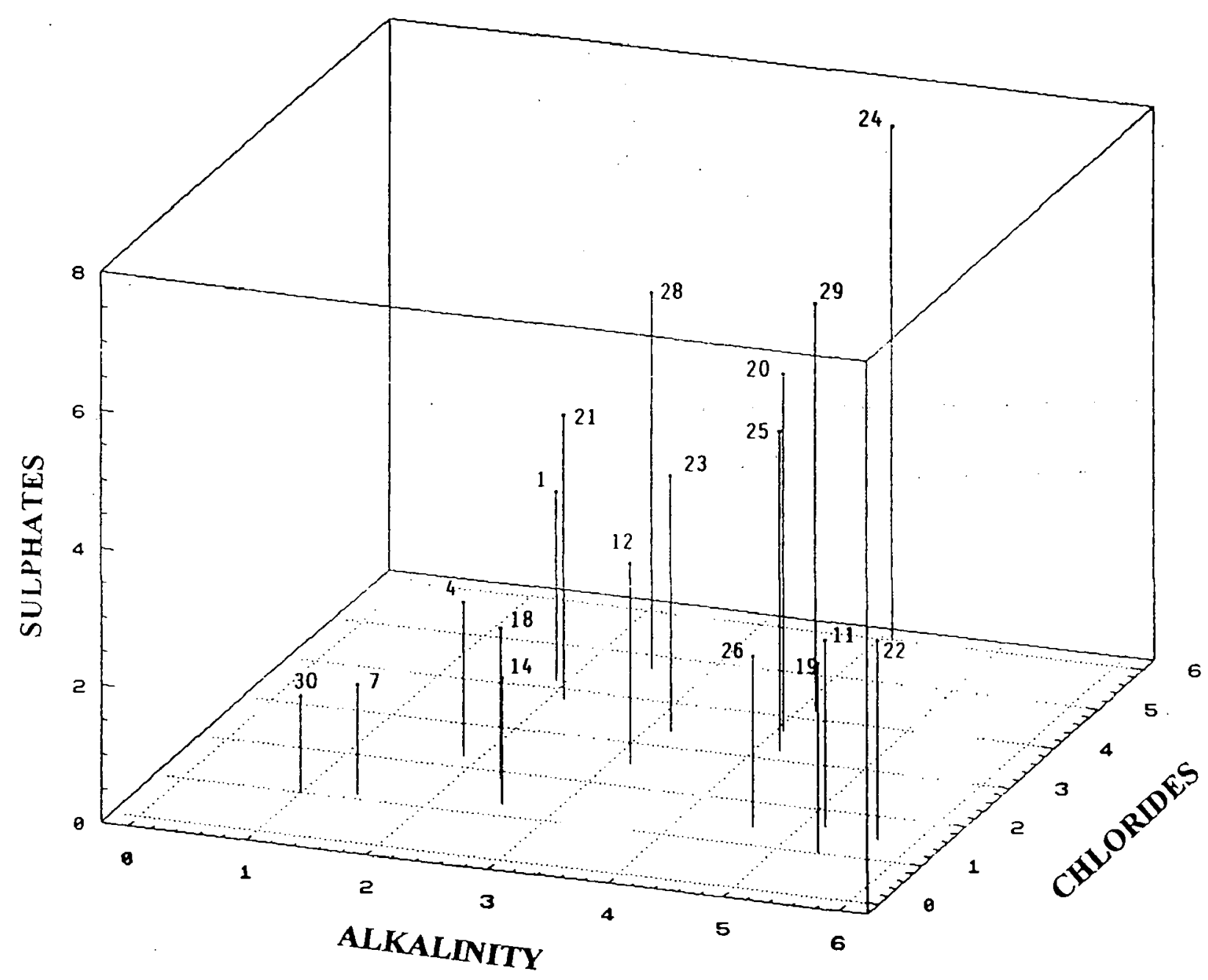

Fig. 8. Representation of the barycenter values for alkalinity, $\mathrm{Cl}^{-}$and $\mathrm{SO}_{4}{ }^{--}$of the 18 taxa that have proved to be indicators of any of the studied parameters. The numbers of species correspond to those in table I.

Fig. 8. Représentation des valeurs de barycentre de l'alcalinité, des chlorures et des sulfates pour les 18 taxa qui peuvent être indicateurs de chacun des paramètres étudiés. Les numéros des espèces correspondent à ceux du tableau I. 


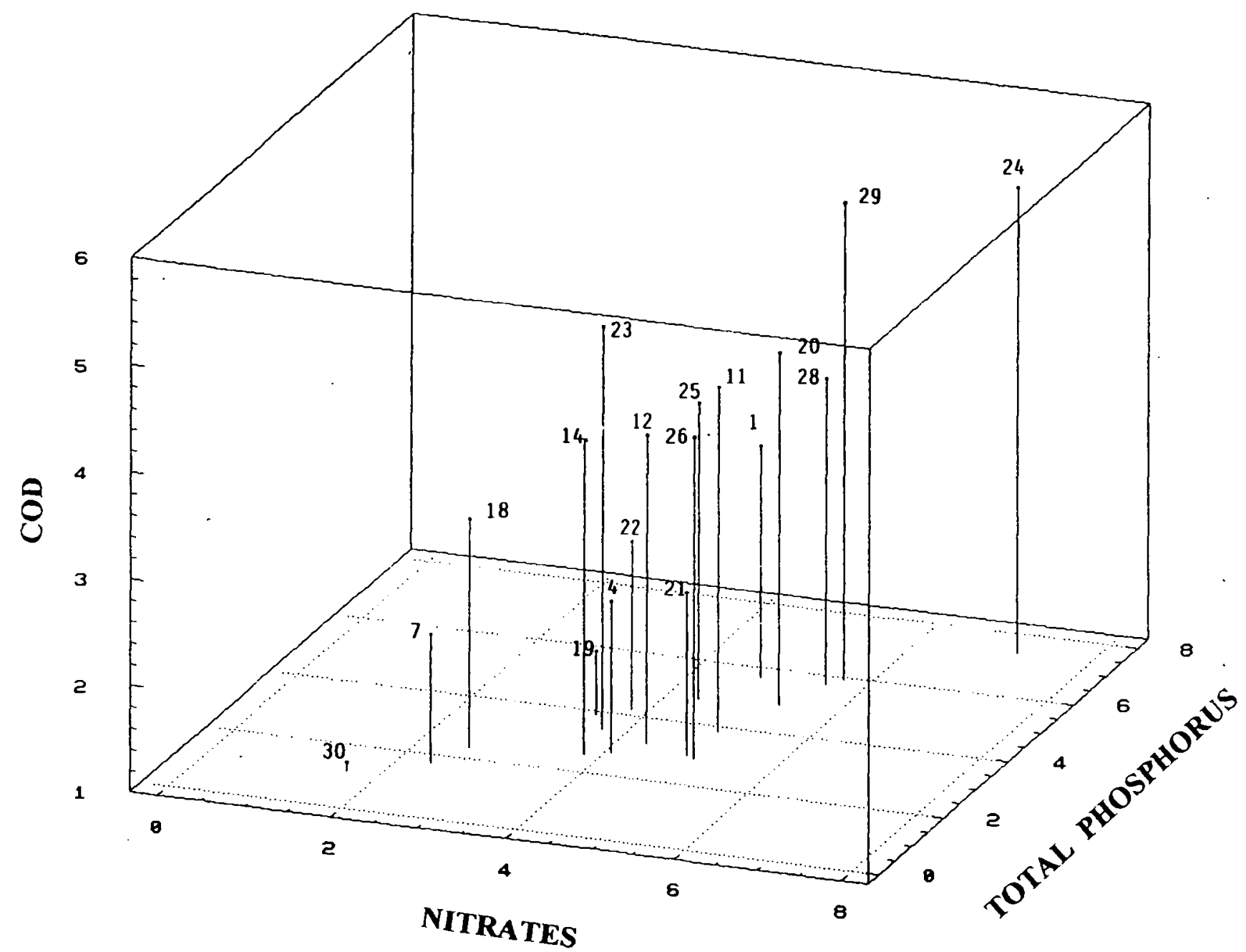

Fig. 9. Representation of the barycenter values for $\mathrm{NO}_{3}{ }^{-}$and total $\mathrm{P}$ concentrations and for COD of the 18 taxa that have proved to be indicators of any of the studied parameters. The numbers of species correspond to those in table I.

Fig. 9. Représentation des valeurs de barycentre des concentrations en nitrates et phosphore total et de la DCO pour les 18 taxa qui peuvent être indicateurs de chacun des paramètres étudiés. Les numéros des espèces correspondent à ceux du tableau I.

At the opposite end are Oulimnius tuberculatus and Hydraena inapicipalpis, both are present at sites with low values for the 6 analysed parameters. Similarly, although to a lesser extent, are Dupophilus brevis, $\mathrm{Hy}$ draena brachymera and Hydraena iberica.

\section{Conclusions}

Among the 32 species of aquatic beetles studied, the most demanding, with respect to water quality, seem to be Hydraena inapicipalpis, Hydraena emarginata and Hydraena iberica. On the other hand, Esolus pygmaeus, Oulimnius rivularis, Oulimnius troglodytes and Elmis maugetii may be regarded as the most tolerant species, although Elmis maugetii does not show preference to the most degraded areas of the basin, but to intermediate ones.

Species of the family Elmidae are in general more tolerant of the slight degree of organic pollution in the study area than those of the family Hydraenidae. This is supported mainly by their responses to factors such as chloride, sulphate and total phosphorus, there being a clear difference between both families.

However, further studies are required in order to discern more distinctly the effect of altitude on this distribution. It would be particularly important to prospect more degraded rivers. Only that way, will it be possible to define the autoecology of these species thoroughly, and state how they respond to the pollution of watercourses. 


\section{References}

Daget P. \& Godron M. 1982. - Analyse fréquentielle de l'Écologie des espèces dans les communautés. Coll. d'Écologie. Masson, Paris, $163 \mathrm{p}$.

Daget P., Godron M. et Guillerm J.L. 1982. — Profils écologiques et information mutuelle entre espèces et facteurs écologiques. In : Grundfragen und Methoden in der Pflanzensoziologie : 191 202.

Díaz Pazos J.A. 1991 — Estudio taxonómico y ecológico de los Hydraenidae (Coleoptera) de la cuenca del río Landro (Lugo, España). Tesis Doctoral en microficha. Universidad de Santiago de Compostela : $515 \mathrm{p}$.

Fernández Aláez M.C., Luis Calabuig E. \& Fernández Alaéz M. 1988. - Caracterización físico-química de la cuenca del río Órbigo (León, España). Actas Col. Luso-Esp. Ecol. Bacias Hidrogr. e Rec. Zoológicos : 103-111.

García Criado F., Fernández Aláez M. \& Régil Cueto J.A. 1994. Datos sobre la ecología de la familia Elmidae en la cuenca del río Órbigo (León, España) (Coleoptera). Boll. Soc. Ent. ital., $126: 200-210$.

García Criado F., Régil Cueto J.A. \& Fernández Aláez M. (in press) - Aspectos ecológicos de la familia Hydraenidae (Coleoptera) en la cuenca del río Órbigo (N.O. España). Zoologica Baetica, 5.

Godron M. 1968. — Quelques applications de la notion de fréquence en écologie végétale (recouvrement, information mutuelle entre espèces et facteurs écologiques, échantillonnage). Oecol. $P l ., 3$ : $185-212$.
Grasser U. 1994. - The Elmidae (Coleoptera) communities of the crystalline Bohemian Mountains in northern Austria in relation to the distribution patterns indicating environmental changes. Verh. Internat. Verein. Limnol., 25 : 1661-1666.

Nakache J.P. 1973. - Influence du codage des données en analyse factorielle des correspondances. Étude d'un exemple pratique médical. Rev. Stat. Appl., $21:$ 57-70.

Puig $\mathrm{M}^{\mathrm{a}}$ A. 1983. - Distribución y ecología de las especies de Elmidae (Col. ; Dryopoidea) de la cuenca del río Llobregat. Boln Asoc. esp. Ent., 7 : 211-219.

Rico E. 1992. - Los Elmidae (Coleoptera : Dryopoidea) de la Península Ibérica e Islas Baleares. Estudio faunístico y análisis de los factores históricos y ecológicos que condicionan su distribución. Tesis Doctoral. Universidad del País Vasco : 276 p.

Sáinz-Cantero C.E. 1985. - Coleópteros de los cursos de agua de Sierra Nevada : taxonomía y ecología de las familias Elmidae, Dryopidae e Hydraenidae. Memoria de Licenciatura. Universidad de Granada : $237 \mathrm{p}$

Sáinz-Cantero C.E. \& Alba-Tercedor J. 1991. - Los Polyphaga acuáticos de Sierra Nevada (Granada, España) (Coleoptera : Hydraenidae, Hydrophilidae, Elmidae, Dryopidae). Boln Asoc. esp. Ent., 15 : 171-198.

Thomas A.G.B. 1988. - La valeur de bioindicateurs des Coléoptères (Elmidae en particulier), comparativement aux autres insectes, face à une violente pollution industrielle (Kraft) en rivière. Annls Soc. Sci. Nat. Archeol. Toulon Var, 40 : 161-167. 